\title{
Geology and gold mineralisation in the Mauken Precambrian basement window, Målselv, Troms, northern Norway
}

\author{
Terje Bjerkgård', Trond Slagstad', lain H.C. Henderson', Jan Sverre Sandstad' \\ \& Johannes Schönenberger ${ }^{1,2}$
}

\author{
${ }^{1}$ Geological Survey of Norway, PO Box 6315 Sluppen, 7491 Trondheim. \\ ${ }^{2}$ Present address: Statoil ASA, Strandvegen 4, 7500 Stjørdal, Norge. \\ E-mail corresponding author (Terje Bjerkgård): terje.bjerkgard@ngu.no
}

\begin{abstract}
The Mauken Precambrian basement window in southern Troms is situated approximately midway between the West Troms Basement Complex (WTBC) and Altevatn-Dividalen basement areas. Work in the Mauken window is part of a NGU project focusing on the basement areas with the main goal to work out a structural-tectonic-metallogenic model and interpretation for the whole region. The window comprises a central unit of metavolcanic and metasedimentary rocks - the Målselva Group, bounded by mainly felsic intrusive rocks to the west,.the Andsfjell-Kampen intrusions, and a very diverse suite of intrusive rocks in the east,.the Øverbygd intrusions. Ages obtained (U-Pb on zircons) on the intrusions range from Neoarchaean to Palaeoproterozoic (2836-1892 Ma). Geochemistry of the greenstone unit in the Myrefjell formation of the Målselva Group indicates an arc/back-arc affinity. The upper part of the Målselva Group, the Aurevatn formation, consists of clastic sedimentary rocks such as siltstone and sandstone, partly forming turbiditic units. On this basis, the Målselva Group must have been formed close to a continent. A granodiorite intruding the greenstone was dated to $2108 \mathrm{Ma}$, meaning that the lower part of the Målselva Group is Palaeoproterozoic or older in age. Regional magnetic data indicate that the most likely continuation of the Mauken window under the Caledonian nappes is to the area between Senja and Kvaløya of the WTBC, and the Astridal and Torsnes belts of supracrustal rocks. The only significant gold mineralisation found in the Mauken window is the so-called 'Main Zone', which is localised in a sand-/siltstone unit close to the contact to underlying greenstone. Gold is associated with and strongly correlated with arsenic. One possible source of the gold and arsenic in this setting is carbonaceous sediments, which are known to concentrate different metals in early formed, diagenetic iron sulphides. A possible formation model for the deposit is that gold, arsenic and sulphur were released from the diagenetic sulphides because of recrystallisation during metamorphism, and that the resulting fluids followed structural pathways, e.g., along or close to the greenstone-sediment contact, and deposited the metals higher up in the sequence. With the size and gold grades of the mineralised zone known today, the mineralisation is not economic. In the RombakTectonic Window of northern Nordland there are some $\mathrm{Au}-\mathrm{As}$ mineralisations which are associated with metagreywacke and metasiltstone. Those mineralisations have been suggested to be of orogenic type, related to shear zones and structures formed during the Palaeoproterozoic, but they also show many similarities with the Mauken mineralisation, suggesting that these too could have formed in the same way.
\end{abstract}

Keywords: Precambrian basement window, bedrock geology, geochemistry, geochronology, gold mineralisation, iron formations

Electronic Supplement 1: Geochemical data.

Electronic Supplement 2: U-Pb zircon data.

Received 17. November 2015 / Accepted 22. June 2016 / Published online 22. July 2016

\section{Introduction}

The Mauken basement window is located in southern Troms, approximately midway between the basement areas of Senja and Altevatnet (Fig. 1). As part of the NGU programme MINN (Mineral Resources in North Norway), the Mauken window has recently been subject to a high-resolution airborne geophysical survey (magnetometry, radiometry and EM; Rodionov et al., 2012), followed by bedrock mapping and structural geology investigations (in progress). The Danish prospecting company Scandinavian Highlands explored the area in the period 2007-2013, looking mainly for gold. 


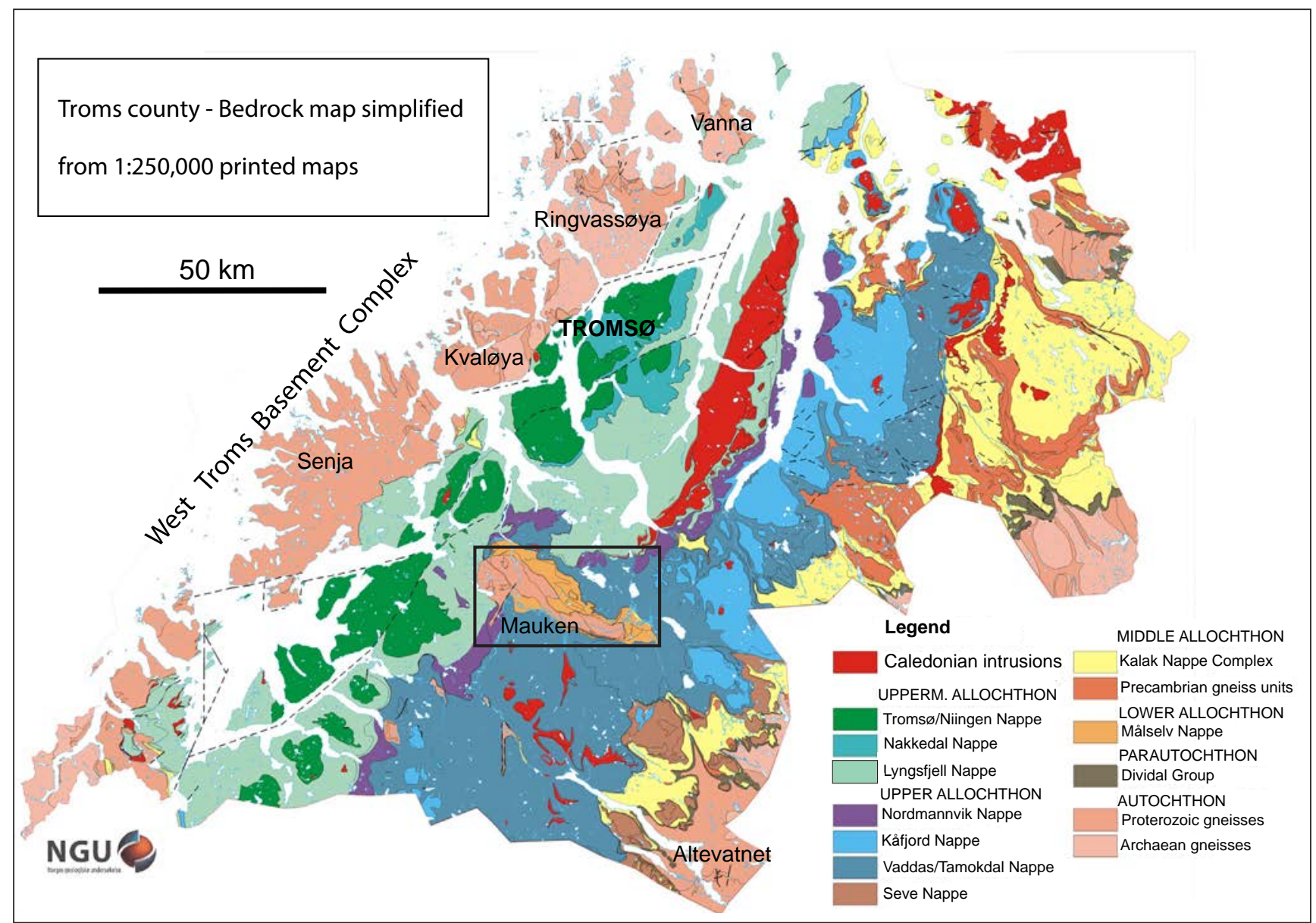

Figure 1. Simplified tectonostratigraphic map of Troms county, based on 1:250,000 bedrock maps published by NGU. The Mauken window is marked by the rectangle.

The work in the Mauken area is part of a larger NGU project focusing on the Precambrian basement areas in southern Troms, including from west to east: the West Troms Basement Complex (WTBC), the Mauken window and the Altevatn-Dividalen area of basement rocks (Fig. 1). The main goal of the project is to work out a structural-tectonic-metallogenic model and interpretation for the whole region. The Mauken window is approximately midway between Senja in the WTBC and Altevatn and is therefore a key area for our understanding and interpretation of the basement history and evolution in this region.

The Mauken window is surrounded by Caledonian nappes that actually separate the window into two parts (Fig. 1). In the north and on the eastern side, the Målselv Nappe comprises mainly sedimentary rocks of Neoproterozoic age (Andresen et al., 1985; Zwaan et al., 1998). To the south and southwest, the Målselv Nappe is overlain by metasedimentary rocks of the Vaddas/ Tamokdal Nappe, also known as the Senja Nappe in this area (Fareth, 1981), comprising mica schist, quartzite and marble (Andresen et al., 1985). The Senja Nappe is structurally overlying the Målselv Nappe. In the west, the window is also in tectonic contact with the Lyngsfjell Nappe, which overlies the Senja Nappe.
Low-grade sedimentary rocks, including conglomerate, sandstone and shale, separate the Precambrian basement from the overlying nappe units in the eastern part of the area. These rocks lie unconformably on top of the older basement rocks and are interpreted to be equivalent to the autochthonous/parautochthonous, Neoproterozoic to Cambrian Dividal Group at the orogenic front (Gustavson, 1963, 1966).

This paper presents results of the work in the Mauken window, and includes results of new mapping of geology and structures, as well as whole-rock geochemistry and geochronology of specific rock units. The results are discussed in relation to published work in the WTBC, Altevatn-Dividalen and other nearby basement areas. A study was also carried out on the main gold mineralisation, and its economic potential and likely formation are also discussed.

\section{Previous work in Mauken}

The first descriptions of the bedrock in the Mauken area were given by the geologist K. Pettersen in 1887 (referenced in Landmark, 1967). He described the 


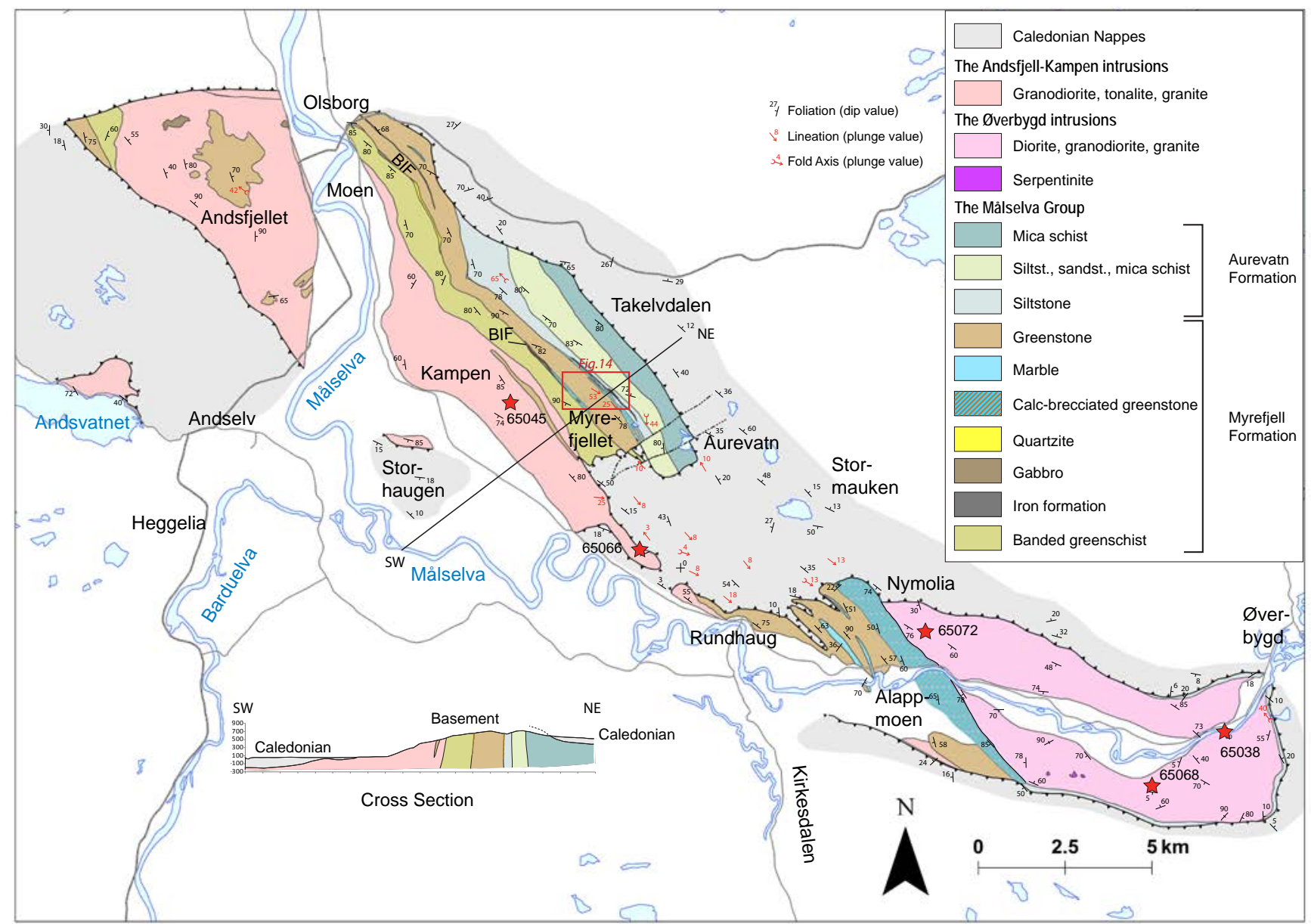

Figure 2. Geology of the Mauken basement window. Red stars with numbers mark samples for geochronology. The rectangle marks the location of the detailed map of the gold mineralisation in Fig. 14. Abbreviation: BIF - Banded iron formations.

"granite" of Mauken and Andsfjell, and noted that there was a discordance between the granite and the overlying schists. On this basis, Pettersen concluded that the granite had to be Precambrian in age.

Gustavson $(1963,1966)$ mapped the basement windows and overlying Caledonian units to the south and east of the Mauken window, and thereby defined and established the extent of the autochthonous cover of metasedimentary rocks in the Dividal Group.

The bedrock geology of the Mauken area has been described in three publications in the NGU yearbook 1966, namely by K. Landmark, A. Berthelsen and F. Kalsbeek \& N.Ø. Olesen. The paper of Kalsbeek \& Olesen (1967) deals mainly with the small basement window to the east of Mauken, where the Dividal Group is well exposed. Berthelsen (1967) divided the Precambrian rocks of the Mauken window into four units, namely (1) the Myrefjell Formation - metavolcanites with intermixed and intercalated metasedimentary rocks, (2) the Aurevatn Formation - various metasedimentary rocks in contact to the metavolcanic units on the north side, (3) the Øverbygd crystalline complex - granodiorite, migmatites, gabbroic to metabasaltic rocks, and (4) the Kampen granodiorite - massive to foliated granodiorite with relics of gneiss. The Myrefjell and Aurevatn formations together were included into the Målselva Group. However, Berthelsen also included part of the Caledonian sedimentary rocks into his Aurevatn Formation. Landmark (1967) gave a thorough description of the geology of the window for his 1:100,000 scale bedrock map 'Målselv' (Landmark, 1959). The paper deals with mineralogy and chemistry of both the granodioritic intrusion and the amphibolites. It also describes the contact relationships with the Caledonian metasedimentary rocks. Landmark seems to have missed the unit of Precambrian metasedimentary rocks (i.e., the Aurevatn Formation of Berthelsen) and included it with the Caledonian units.

On the preliminary 1:50,000 bedrock map 'Takvatnet' by Fareth (1982) and the 1:250,000 map 'Tromsø' (Zwaan et al., 1998), the interpretation by Landmark (1967) described above is retained. Thus, the Aurevatn Formation introduced by Berthelsen (1967) is disregarded, and is replaced by a far too extensive unit of amphibolite. 


\section{Geology of the Mauken window}

The Mauken window is naturally divided into three main areas based on geology (Fig. 2): (1) The AndsfjellKampen intrusions: The area comprises various felsic intrusive rocks, and is divided into two subareas by the Målselva river; the Andsfjellet part in the west and the Kampen part in the east including the western slopes of Mauken from Moen to Rundhaug. (2) The Målselva Group: A central unit of volcanic and sedimentary rocks, extending from Olsborg in the northwest to Alappmoen in the southeast. (3) The Øverbygd intrusions: a very diverse, mainly intrusive suite which includes ultramafic, mafic and intermediate to felsic rocks present in the eastern part of the window.
In the area between Grønkampen, Nymolia and Rundhaug, the basement rocks are overlain by Caledonian units, dividing the basement window into two parts (Fig. 2).

\section{The Andsfjell-Kampen intrusions}

This area of intrusive rocks dominates at Andsfjellet and continues along the southwestern, steep slopes of the valley of Målselvdalen from Moen and 7-8 km southeastwards to Rundhaug (Fig. 2). It is also present in outcrop and road sections to the west of Andselv, along the northern shores of Andsvatnet.
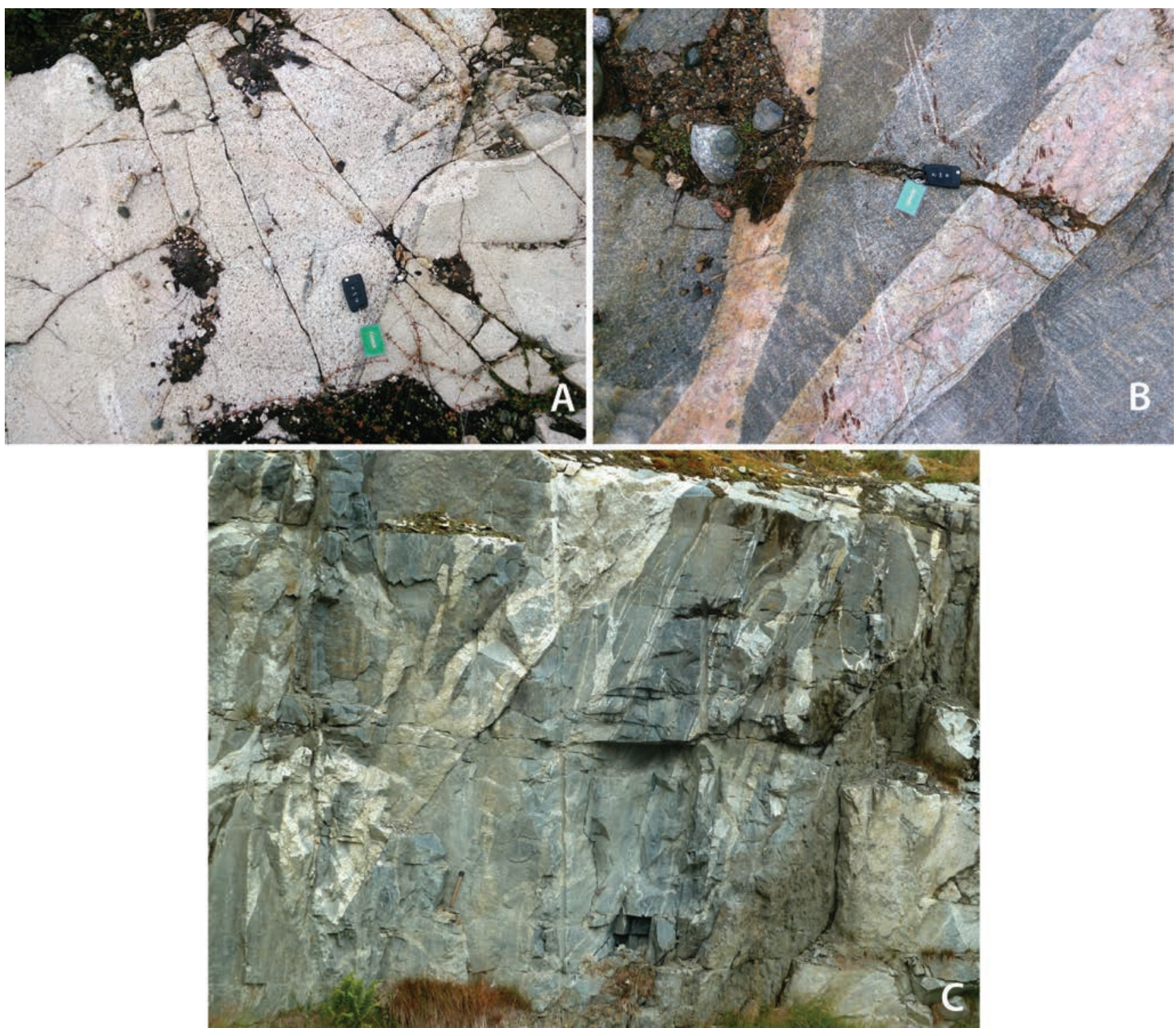

Figure 3. (A) Granitic phase (left - pinkish coarser) intruding trondhjemite/tonalite (right-greyish finer grained). Locality: Målselv ski resort UTM 408537, 7664255. (B) Relatively dark granodiorite intruded by veins of granitic pegmatite. Locality: Målselv ski resort UTM 408500, 7664376. (C) Veins of trondhjemite intruding greenstone. Locality: The road to Målselv ski resort, UTM 408988, 7663980. 
The geology of the area comprises several intrusive phases with compositions varying from tonalite/trondhjemite to granodiorite and granite (Fig. 3A, B). However, large parts of the intrusions in the Kampen area to the east of Målselva are fairly homogeneous, comprising light-grey granodiorite with a grain size of 2-5 mm. At Andsfjellet, a fairly large proportion of the intrusion is of granitic composition. Quartz veins and pegmatites of granitic composition varying in width from a few centimetres up to $c .50 \mathrm{~cm}$ are also common on Andsfjellet.

In the river Takelva close to Olsborg there are outcrops of a very fine-grained, strongly foliated to laminated, felsic rock composed of quartz, feldspar, muscovite, biotite and epidote/clinozoisite. This rock type is situated at the boundary between greenschist and greenstone, and is most likely a fine-grained (aplitic?) magmatic rock related to the larger unit of the Kampen intrusions.

Fine-grained mafic rocks with a microgabbroic texture form enclaves within the felsic intrusions in some places on Andsfjellet. The grain size of amphibole varies from $1 \mathrm{~mm}$ up to $c .1 \mathrm{~cm}$, while feldspar laths are up to $10 \mathrm{~mm}$ in length. Some of these gabbroic bodies cover larger areas and appear to be fairly homogeneous in composition apart from the variation in grain size. There are no granitic veins/pegmatites intruding the gabbroic rock (or vice versa) and the contact to the surrounding granitoid is rather sharp. The homogeneity and sharp contacts suggest that these are intrusive bodies rather than altered metavolcanic xenoliths in the granitoid rock. Other

\section{Simplified lithostratigraphic column for the Målselva Group}

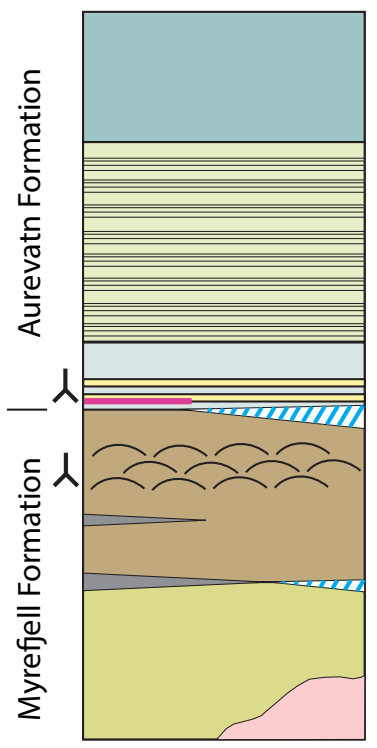

Mica schist, partly calcareous

Rhythmic alternating silt- to sandstone turbiditic origin?

Siltstone with sandstone layers Gold mineralisation - 'Main Zone' Marble and calc-brecciated greenstone

Greenstone/metabasalt pillowed, massive flows, BIF

BIF and calc-brecciated greenstone

Banded greenschist/metatuffite

Granodioritic intrusion (2108 Ma)

Figure 4. Schematic stratigraphic profile through the Målselva Group from southwest to northeast. Abbreviation: BIF-Banded iron formations. gabbroic rocks are interpreted to be dykes, intruding the felsic rocks.

The intrusive character of the felsic rocks is evident at several places. On Andsfjellet, a number of mafic bodies are found as rafts within the intrusion, and they are locally intruded by a number of dykes rooted in the main felsic intrusion. To the west of Myrefjellet, smaller and larger lenses and layers of greenstone are incorporated in the granodiorite. Veins of the felsic rocks intrude the greenschist and greenstone (Fig. 3C). Thin sills (some metres thick) of more fine-grained felsic rock are also found up to several hundred metres inside the greenschist unit.

The Kampen part of the intrusion contains quartz, plagioclase and $\mathrm{K}$-feldspar as main phases, while biotite is a common subordinate mineral. The content of K-feldspar varies, and accordingly the rock classifies as either trondhjemite, tonalite, granodiorite or granite. Muscovite, clinoamphibole and epidote are the most common accessory phases.

On Andsfjellet the felsic rock is mainly leucocratic with abundant quartz, K-feldspar and usually low but varying amounts of plagioclase (granite to granodiorite). The content of biotite is very low. Thin-sections reveal accessory titanite, muscovite, Fe-oxides, greenish amphibole and locally late calcite.

\section{The Målselva Group}

The Målselva Group comprises mainly mafic metavolcanic and fine-grained metasedimentary rocks, and is situated centrally in the window, bounded by intrusions in the west and east (Fig. 2). The foliation in the unit strikes mainly NW-SE and is mostly steeply dipping to the southwest or vertical.

The name Målselva Group was suggested by Berthelsen (1967) to include all the supracrustal rocks in the Mauken window, and this definition is retained in this paper. The boundary to the felsic Andsfjell-Kampen intrusions is sharp, as described above, whereas the boundary to the Øverbygd intrusions is of tectonic character (see below). Between Aurevatn and Rundhaug and in Takelvdalen, the Målselva Group is structurally overlain by Caledonian nappes consisting mostly of metasedimentary rocks (Fig. 2).

The Målselva supracrustals comprise mainly (from southwest to northeast; Figs. 2 \& 4) banded/ laminated (probably volcaniclastic) greenschist, greenstone, siltstone, sandstone and mica schist. Units of calc-brecciated greenstone, small gabbroic bodies and iron formations are also present. The metavolcanic units were collectively named the Myrefjell Formation and the metasedimentary rocks the Aurevatn Formation by Berthelsen (1967). The names are retained in this paper (Fig. 4). 
However, Berthelsen (op. cit.) also included parts of the Caledonian nappes into his Aurevatn Formation.

Banded greenschist belonging to the Myrefjell Formation occupies a c. $12 \mathrm{~km}$-long and 6-700 m-wide belt from Moen and southeastwards to Myrefjellet (Fig. 2), between the Andsfjell-Kampen intrusions and the unit of massive greenstone. A similar banded unit is found on the western side of Andsfjellet.

The greenschist is generally strongly laminated and banded on $\mathrm{mm}$ to $\mathrm{cm}$ scale, with alternating paler greyish and darker greenish bands. The lighter bands are enriched in quartz and plagioclase, whereas the darker bands are rich in chlorite, amphibole and/or epidote. Some of the banded layers are also generally more felsic. Within the unit there are also several more massive layers of greenstone. On the basis of the banded to laminated character, as well as the mineralogy, the greenschist unit is interpreted to be of volcaniclastic origin.

Close to the northern boundary of the unit is a 5-20 $\mathrm{m}$-thick layer of greenschist enriched in magnetite. This layer contains bands with $2-4 \%$ of magnetite (measurements by hand-held susceptibility meter; Fig. 5A).

The greenstone of the Myrefjell Formation occurs in a 500-1000 m-wide belt to the north of the unit of banded greenschist. It extends from Olsborg to Myrefjellet, is tectonically overlain by the Caledonian units between Aurevatn and Rundhaug, and continues on the south side of the river Målselva close to Alappmoen (Fig. 2). A similar unit of greenstone is also found on the western side of Andsfjellet.

In the Olsborg-Myrefjellet segment (Fig. 2), the northern contact of the greenstone is against fine-grained metasedimentary rocks (originally siltstone). The greenstone close to this contact is calc-brecciated in the eastern part of the segment, with a few thin, intercalated lenses of calcite marble. In the Rundhaug-Alappmoen segment, the northern contact is marked by a thick unit (up to 2-300 m) of calc-brecciated greenstone. In this part of the greenstone there are also intercalated thicker lenses of calcite marble.
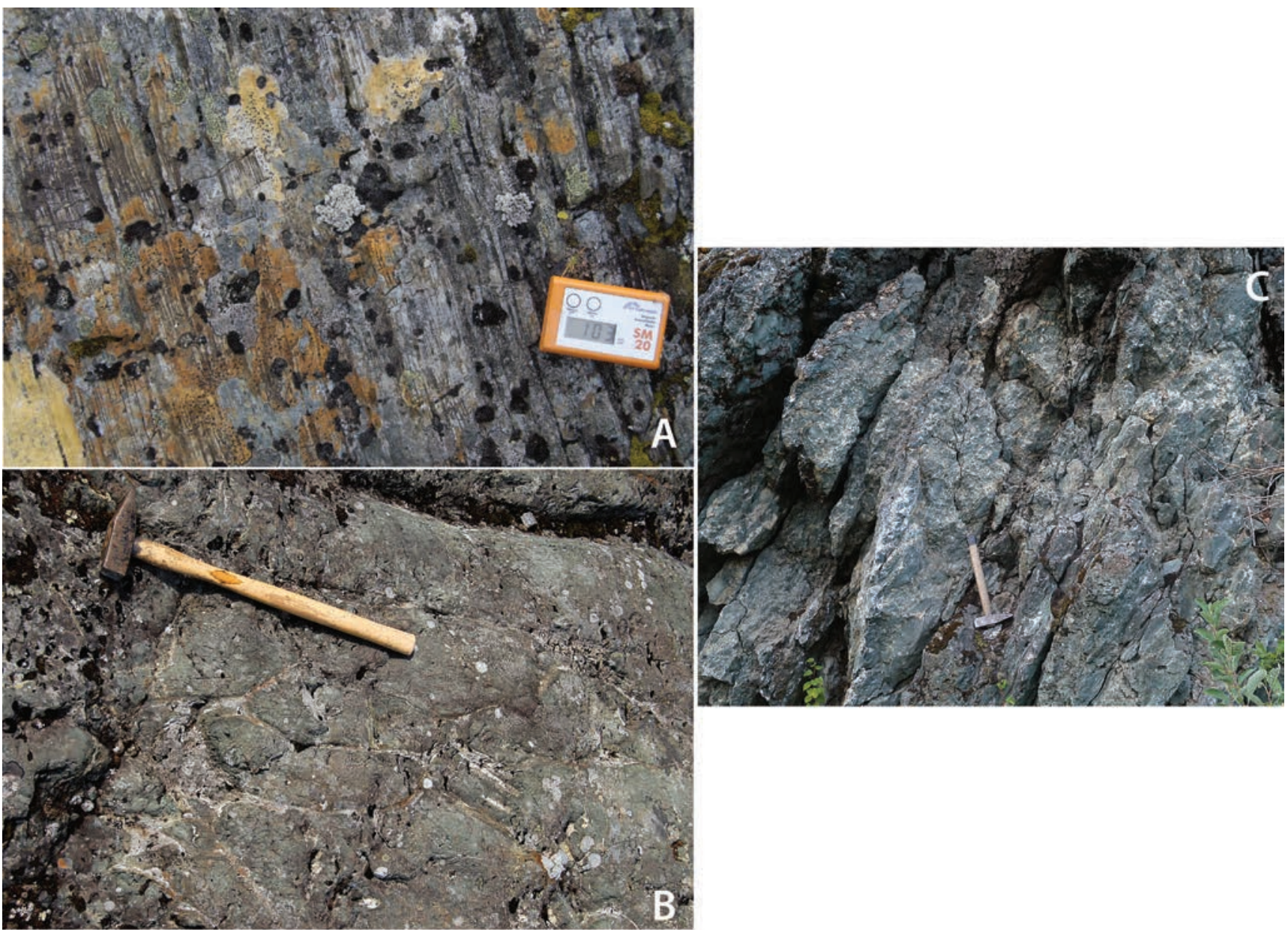

Figure 5. (A) Strongly banded magnetite-rich schist, with alternating quartz-rich and magnetite-rich bands. The susceptibility meter shows a value of $103 \times 10^{-3}$ SI units, corresponding to c. 3\% magnetite in the rock. The length of the instrument is $10 \mathrm{~cm}$. (B) Pillowed metabasalts at Myrefjellet (UTM 411740, 7664760). The shape of the pillows indicates that right-way-up is up in the photo, which is towards the north. (C) Typical calc-brecciated greenstone. Locality: Road section east of Rundhaug, UTM 421360, 7656750. 
In the Myrefjellet area, the greenstone consists mainly of 1-3 m-thick massive layers, separated by more schistose or brecciated thin bands and layers. These massive layers are interpreted to represent basaltic flows, the brecciated bands being the quenched margins. At several localities these layers consist of well preserved pillowed metabasalts (Fig. 5B), and some indicate that right-way-up is towards the northeast. In many places the greenstone is either porphyritic with mm-sized white grains of plagioclase, or has a microgabbroic texture.

Clinoamphibole and plagioclase are the main phases in the greenstone. In a few places, epidote is a major phase, but is more often present as a subordinate mineral together with quartz and chlorite. Titanite and biotite are subordinate to accessory minerals, while carbonate, sericite and iron oxides/sulphides are common accessory phases.

An extensive layer of calc-brecciated greenstone is situated to the north of the greenstone unit in the AlappmoenNymolia area, also part of the Myrefjell Formation (Fig. 2). It is more than $7 \mathrm{~km}$ long and 300-900 m thick.
Similar, but much less extensive layers occur on both sides of the massive greenstone unit in the Myrefjellet area (Fig. 2).

This rock type consists of fragments of greenstone in an irregular network of white calcite (Fig. 5C). In places, larger lenses of calcite are found within the greenstone. Thus, one possibility (most likely?) is that this rock formed during deformation with subsequent infiltration and formation of calcite from the surrounding carbonate layers. The content of calcium in these lenses is too high to have derived from breakdown of e.g., pyroxene and plagioclase from the original greenstone.

The calc-brecciated greenstone is strongly altered and consists mainly of chlorite, quartz and calcite, with subordinate plagioclase. The rock is enriched in magnetite, which occurs in subordinate to accessory amounts. The content of magnetite (up to 3-4\%) gives the rock a strong magnetic anomaly that can be traced even through the overlying Caledonian thrust sheets (Rodionov et al., 2012).
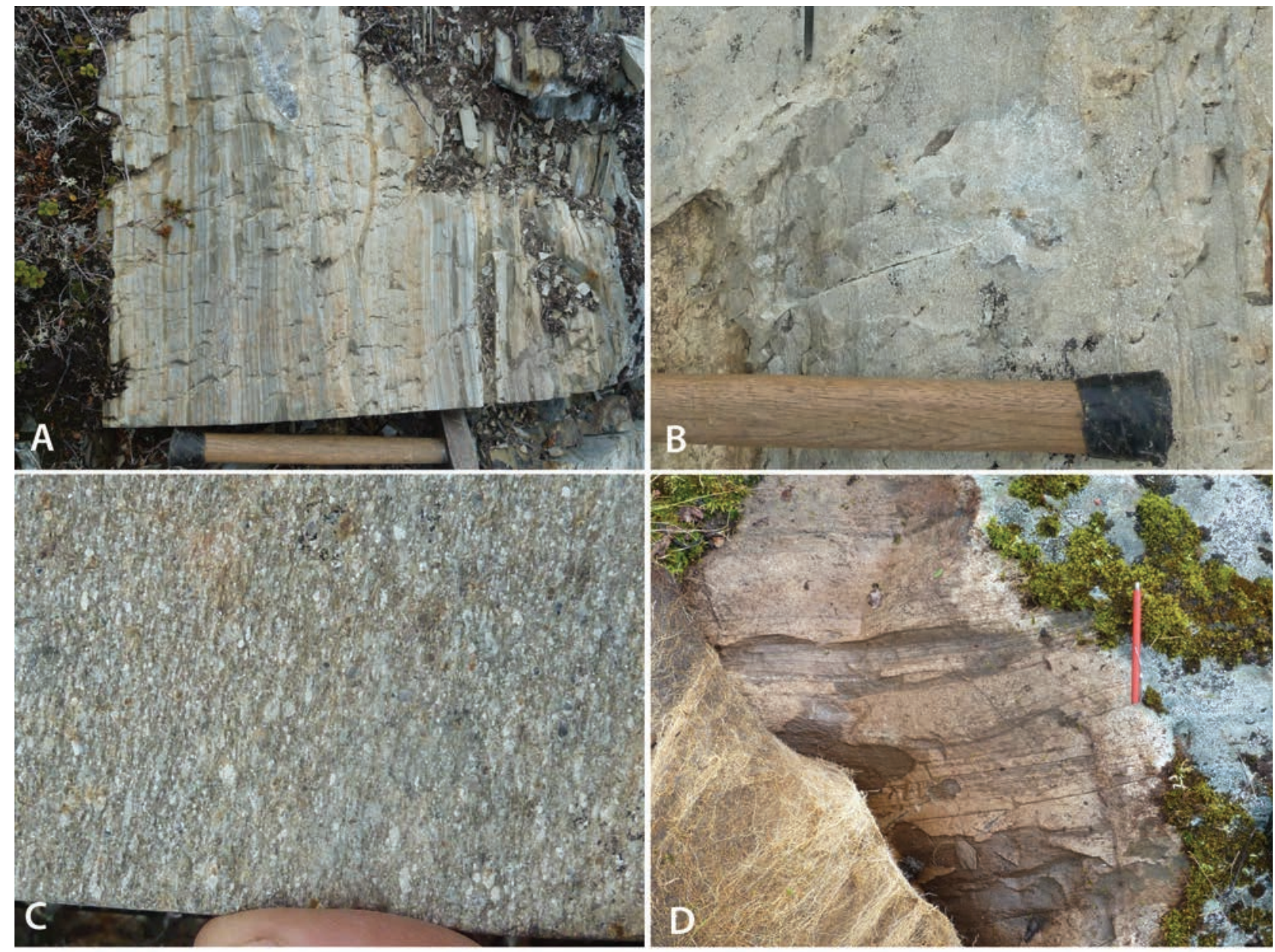

Figure 6. (A) Typical laminated siltstone. Locality: To the north of Myrefjellet, UTM 411930, 7664960. (B) Alternating fine-and coarse-grained sandstone, showing graded bedding. Locality: To the north of Myrefjellet, UTM 412370, 7664585. (C) Close-up photo of rather coarse-grained layer of sandstone. Same locality as in (B). (D) Laminated to banded sandstone, with trough-like structure, indicating that right-way-up is to the north. Locality: northwest of Myrefjellet, UTM 409135, 7667545. 

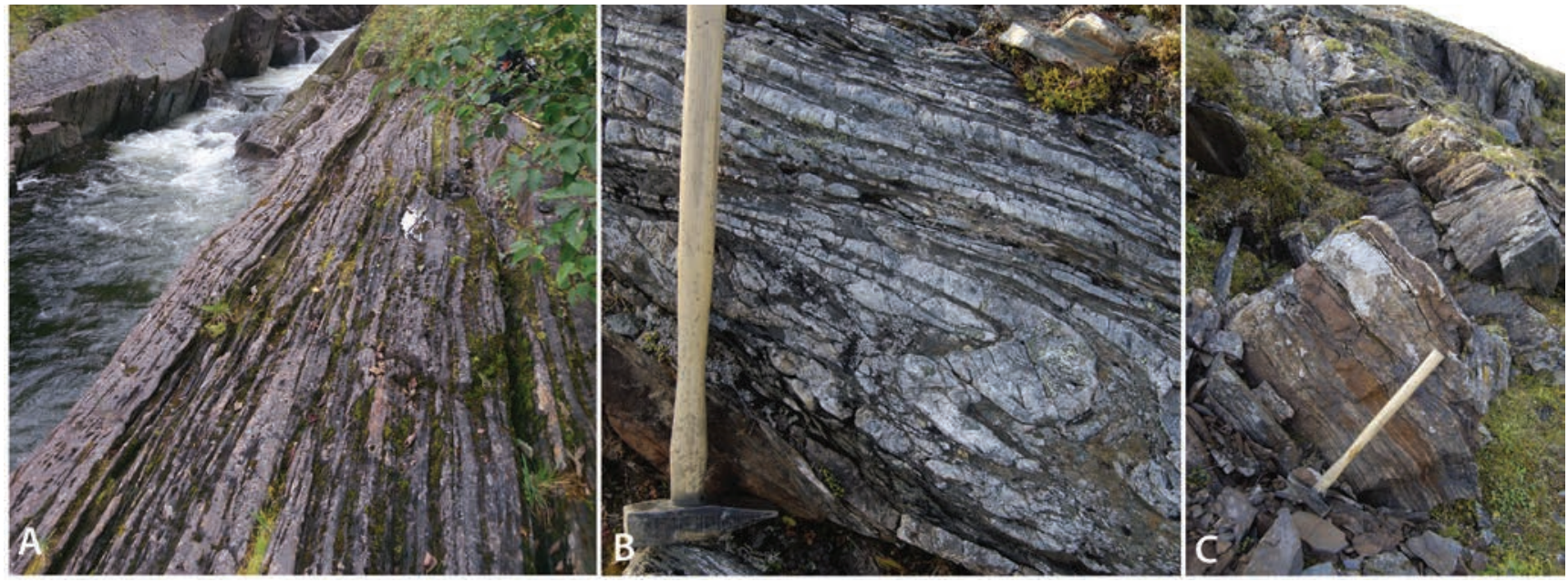

Figure 7. (A) Outcrop of banded iron formation in Takelva. The photo is taken looking east. On the north side of the river is chloritic greenschist. (B, C) Outcrops from the iron formation in the Bjelma valley. Photo (B) shows a banded quartz-rich unit, while photo (C) shows a banded carbonate-rich unit, where the carbonate is brown and iron rich.

The sedimentary Aurevatn Formation comprises mainly metasiltstone, metasandstone and mica schist (Fig. 4), and is present in the northern and central parts of the window, in the area between Aurevatn and Olsborg (Fig. 2 ). The formation has a maximum thickness of more than $1.5 \mathrm{~km}$ to the north of Myrefjellet, before it is overlain by one of the Caledonian nappes. This unit is important, as it hosts the main gold mineralisation in the Mauken area (see below; Fig. 4).

Close to the contact to the greenstone unit, the westernmost 100-150 metres of the sedimentary rocks are dominated by laminated metasiltstone. It is in this siltstone unit that the gold mineralisation is situated. Within the siltstone there are also several thin layers ( 1 to $4 \mathrm{~m}$ thick) of fine- to more coarse-grained metasandstone, but thicker sandstone layers are also present.

The metasiltstone is typically finely laminated on $\mathrm{mm}$ to $\mathrm{cm}$ scale, with alternating darker and lighter bands (Fig. 6A). The dark bands are enriched in biotite and/or graphite, while the lighter layers contain more quartz and sericite/muscovite. The banding is also due to variations in grain size. Other minerals in the metasiltstone are chlorite, tourmaline and apatite. The content of graphite in the siltstone appears to increase to the southwest towards the greenstone contact.

The sandstone beds within the siltstone vary from very fine grained to relatively coarse grained, and commonly display graded bedding (Fig. 6B, C). In some cases, structures reminiscent of.cross-bedding and trough-like features are recognised, indicating that right-way-up is northwards (Fig. 6D). The subrounded clasts consist mainly of quartz and sericitised feldspar, but the sandstone also contains a few clasts of very fine-grained quartz-feldspar rock.
Farther northeast, the siltstone grades into more massive metasandstone, with a rhythmic banding on metre-scale between finer silty and coarser sandy layers. This part of the unit, reaching 500-700 $\mathrm{m}$ in thickness, could possibly represent turbidites.

Farthest to the northeast, and in contact with the Caledonian thrust sheets, is a 500-600 m-thick unit of more homogeneous, fine-grained, dark mica schist dominated by quartz and biotite, but also containing subordinate amounts of carbonate, especially close to the metasandstone unit. The contact between the sandstone and schist is marked by a small valley.

The contacts between the various lithologies within the Målselva Group in the Myrefjellet area seem to be mainly of primary origin. However, the calc-brecciated greenstone present close to, and at the contact between some of the main lithological units (Figs. 2 \& 5), shows that strong deformation took place at some stage, possibly during emplacement of the Caledonian nappes.

As shown above, at several localities in the sedimentary sections of the Målselva Group, primary structures such as cross-bedding, graded beds, etc., show a consistent picture, i.e., indicating that right-way-up is towards the north. The shapes of pillows in the greenstone unit also indicate that right-way-up is towards the north.

Based on the mineralogy of the supracrustal rocks of the Målselva Group, the grade of metamorphism is generally low. A typical mineral assemblage in the greenstone/ greenschist is albite, chlorite, epidote, biotite and actinolite, and the metasiltstone (pelitic schist) is dominated by quartz, sericite/muscovite, chlorite and biotite. Garnet has been found in just a few localities, and only as tiny grains in thin-sections. On this basis, the metamorphic grade seems only locally to have exceeded middle greenschist-facies conditions. 


\section{Banded iron formations}

There are two magnetite-dominated banded iron formations in the Mauken window, both situated in the Målselva Group (Fig. 4). One is situated within the major greenstone unit to the north of Myrefjellet and one is located along the boundary between the banded greenschist and greenstone to the west of Myrefjellet (both marked as BIF in Fig. 2).

The northernmost iron formation forms an extensive layer within the major greenstone unit, stretching southeastwards from the main road (E6) at Olsborg in the northwest (Fig. 2). It shows up as a strong magnetic anomaly (Rodionov et al., 2012). The total length of the zone is more than $3.5 \mathrm{~km}$, while the thickness is $6-7 \mathrm{~m}$. The northernmost outcrop of the zone is in the river Takelva, where it is a strongly foliated, and laminated on a few centimetre scale, quartz- and carbonate-rich, iron formation, some 6-7 m thick (Fig. 7A). The outcrop displays isoclinal folding with the development of a transposition foliation. In the south, it shows more of an irregular banding, partly with lenses of fine-grained magnetite and quartz. The northern outcrop contains quartz, carbonate and magnetite as major phases, with pyrite, chlorite and biotite as accessories. The southern outcrop is dominated by quartz and magnetite, and carbonate is absent. Chlorite and grunerite (iron-rich amphibole) are subordinate phases.

The other iron formation is exposed in the pronounced Bjelma valley to the west of Myrefjellet (Fig. 2). This valley marks the boundary between the banded, tuffitic greenschist and the generally massive greenstone/metabasalt. The iron formation is located in the northwestern part of this valley, in the extension of a layer of calcbrecciated greenstone. It has a length of at least $700 \mathrm{~m}$ and a thickness of up to $30 \mathrm{~m}$ close to the major bend of the stream in the valley.

The iron formation varies in composition across strike, from quartz- to carbonate-rich (Fig. 7B, C). The carbonate is generally a brown, Fe-rich calcite or ankerite. Fine-grained magnetite is present in thin bands throughout the unit, and the thin bands are generally found in zones less than one metre in thickness. Some zones in the formation are enriched in sulphides, mainly pyrite.

\section{The $\varnothing$ verbygd intrusions}

The area of intrusive rocks close to Øverbygd stretches from Alappmoen in the west to Øverbygd in the east (Fig. 2). In the west, it has a tectonic contact to the Målselva Group, with a gradually increasing shear deformation of the granodiorite westwards towards the contact. This contact is well exposed along the main road between Rundhaug and Øverbygd. In the east and south, the intrusions are unconformably overlain by sedimentary rocks (mainly siltstone) correlated with the
Neoproterozoic/Cambrian Dividal Group (Gustavson, 1963, 1966).

The Øverbygd area comprises a very diverse suite of magmatic, mainly intrusive rocks. The main rock types are granite, granodiorite and gabbro, while monzonite, diorite and ultramafic rocks are less common.

The area has not been mapped in detail, but granodiorite is generally dominating to the north of the river, whereas granite is most common in the south. Monzonitic to dioritic rocks are present in the easternmost part of the area. There are complex relationships between the different intrusive phases in the area, but from the field observations the granitic rocks seem to be the latest phase.

On the southern side of the river, to the east of Alappmoen, there are some small bodies of serpentinite which also includes soapstone. These bodies are situated in mainly granitic rocks, together with lenses of greenstone (Lindahl \& Nilsson, 2002; Nilsson \& Lindahl, 2005). The soapstone appears to be of partly good quality and has also been evaluated for dimension stone (op.cit.).

\section{Contact to the Caledonian nappes}

On Andsfjellet, the boundaries of the tectonic window to the surrounding Caledonian rocks are evident, as there is a marked contrast in rock type (Caledonian schists vs. Precambrian intrusive rocks) as well as dip of foliation (Caledonian rather flat up to $20-40^{\circ}$, Precambrian typically much steeper i.e., $60-90^{\circ}$ ). The contact is commonly characterised by a considerable enrichment in quartz veins. Some quartz veins are folded into the Caledonian rocks, while others cross-cut the granitic rocks. In the contact area, the granite is commonly strongly sheared parallel to the overlying Caledonian rocks, but this zone is only $c .1 \mathrm{~m}$ wide, suggesting that the Caledonian reworking of the underlying basement in this area is limited.

Similar structural contrasts are also found in the central part of the area; flat-lying Caledonian lithologies are present in contact with steep to nearly vertically dipping basement rocks. The Caledonian schists are generally strongly foliated and sheared and typically display an $\mathrm{S}-\mathrm{C}$ fabric indicating top-to-the-east kinematics.

In the south, rocks of the Øverbygd intrusions are overlain by mainly very fine-grained metasiltstone, which is interpreted to be part of the Dividal Group (Gustavson, 1966). This unit is only a few tens of metres thick, and is followed above by quartzitic rocks of the Caledonian nappes. The quartzite is strongly deformed, with the development of large-scale isoclinal folding.

The northern contact of the window with the overlying Caledonian nappes close to Takelva (see Fig. 2) is more 


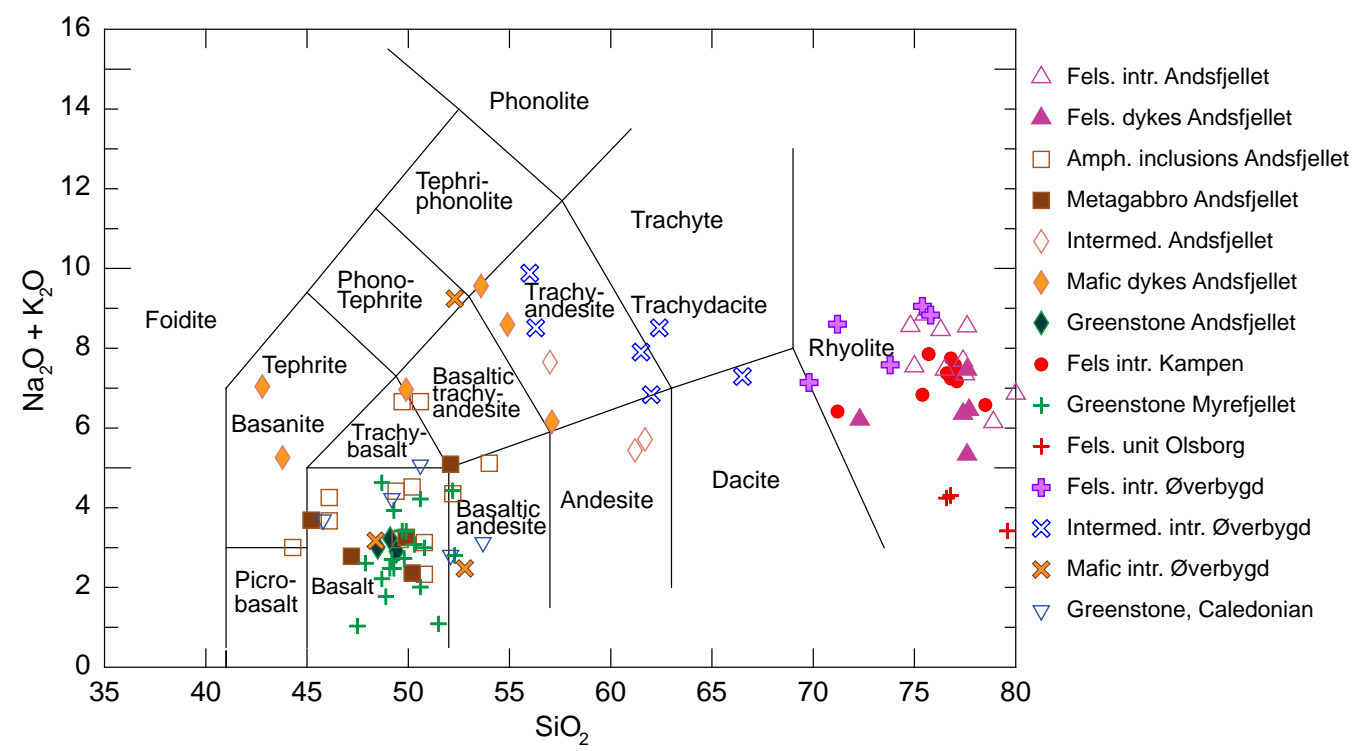

Figure 8. Samples of the magmatic rocks in the Mauken area plotted in the $\mathrm{SiO}_{2} v s . \mathrm{Na}_{2} \mathrm{O}+\mathrm{K}_{2} \mathrm{O}$ diagram of Le Bas et al. (1986).

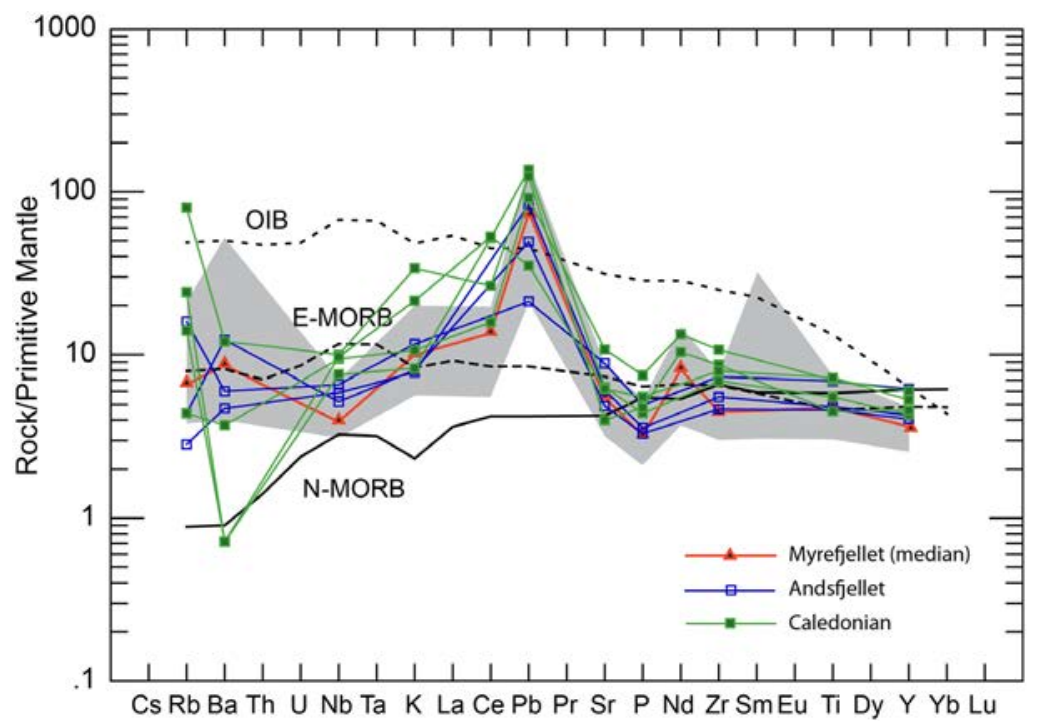

Figure 9. Greenstones from Andsfjellet, Myrefjellet and the overlying Caledonian units plotted in a primitive mantle-normalised diagram. The range of the Myrefjellet greenstone samples is shown in grey shading, while the median of the corresponding samples are shown by the red curve. Normalising values are taken from Sun \& McDonough (1989).

difficult to define. This is due to the fact that similar mica schist lithologies (i.e., similar mineralogy and metamorphic grade) are present in both the Precambrian rocks and the overlying Caledonian nappes. However, small-scale structural and kinematic differences in strike-slip crenulation cleavage in the underlying Precambrian rocks and clear top-to-theeast thrust kinematics in the overlying Caledonian nappes permit a precise mapping of the boundary.

\section{Geochemistry}

131 samples were collected for geochemistry (Electronic Supplement 1), comprising all the major lithologies in the area, but focusing on the magmatic rocks. Major and trace elements were analysed at the Geological Survey of Norway (NGU), Trondheim, by a PANalytical Axios at 4 $\mathrm{kW}$ X-ray spectrometer. The precision $(1 \sigma)$ is typically $1-2 \%$ of the major oxide present.

Fig. 8 shows the analytical data for the magmatic rocks in the area in the $\mathrm{SiO}_{2}$ vs. $\mathrm{Na}_{2} \mathrm{O}+\mathrm{K}_{2} \mathrm{O}$ diagram of Le Bas et al. (1986). Most of the mafic rocks are of basaltic/ gabbroic compositions and the felsic rocks of rhyolitic/ granitic compositions. Samples of more intermediate and alkaline compositions mainly come from the eastern part of the window (the Øverbygd area), but are also represented by mafic dykes and intermediate rocks from the Andsfjell area. 


\section{Mafic volcanic rocks}

The greenstone units at Myrefjellet (excluding the tuffitic greenschist), on the northwestern side of Andsfjellet and in the overlying Caledonian units are compared in a mantle-normalised spider diagram in Fig. 9.

The diagram shows that the chemistry of the greenstone units is quite similar, except that the Caledonian greenstone samples show more scattered patterns than the samples from the window. All three units show enrichments in the LIL elements $\mathrm{K}, \mathrm{Rb}$ and $\mathrm{Ba}$ compared to $\mathrm{N}-\mathrm{MORB}$, and depletion in the HFS elements $\mathrm{Zr}$ and $\mathrm{Y}$. The data also show very high values of $\mathrm{Pb}$, and a slight depletion in $\mathrm{Nb}$ compared to N-MORB. The data are most compatible with formation in a back-arc to arc environment.

\section{The Andsfjell-Kampen intrusions}

The chemistry of the major, felsic, Andsfjell-Kampen intrusive units, as well some dykes from Andsfjellet and the fine-grained aplite from Olsborg, are shown in the ORG (Ocean Ridge Granite) normalised diagrams in Fig. 10. The diagrams show a very similar pattern for the majority of samples from Andsfjellet and Kampen and also the Olsborg aplitic unit. Most samples are strongly enriched in the LIL elements ( $\mathrm{K}, \mathrm{Rb}, \mathrm{Ba}, \mathrm{Th})$ compared to ORG, and generally accord with WPG (Within Plate Granite). A few samples from Andsfjellet, which include both the main intrusion and dykes, show low values of $\mathrm{K}, \mathrm{Rb}$ and $\mathrm{Ba}$, perhaps due to differentiation. Samples from the Øverbygd intrusions are more diverse, but overall show much lower values for $\mathrm{Nb}, \mathrm{Y}$ and $\mathrm{Zr}$, compared with the Andsfjell-Kampen intrusions, and thus seem most likely to have a different origin than the latter.

The late, fine-grained, mafic intrusions (dykes and metagabbro) and amphibolitic inclusions in the felsic Andsfjellet granite/granodiorite have a different geochemistry than the greenstone units as shown in the primitive mantle-normalised diagram (Fig. 11). They are strongly enriched in $\mathrm{Rb}, \mathrm{Ba}, \mathrm{Nb}$ and $\mathrm{K}$, as well as $\mathrm{P}, \mathrm{Nd}$ and Zr. Thus, these rocks appear to have a similar origin to that of the major felsic intrusions.

\section{Geochronology}

Five samples of the main felsic intrusive rocks have been dated, including two from the central Kampen granodiorite and three from the Øverbygd intrusions (Fig. 2). The data are presented in Electronic Supplement 2.

Zircons were separated by standard techniques including water table, heavy liquids, magnetic separation and final hand picking under a binocular microscope. The zircons were mounted in epoxy and polished to approximately half thickness, and cathodoluminescence (CL) images were obtained with a scanning electron microscope to
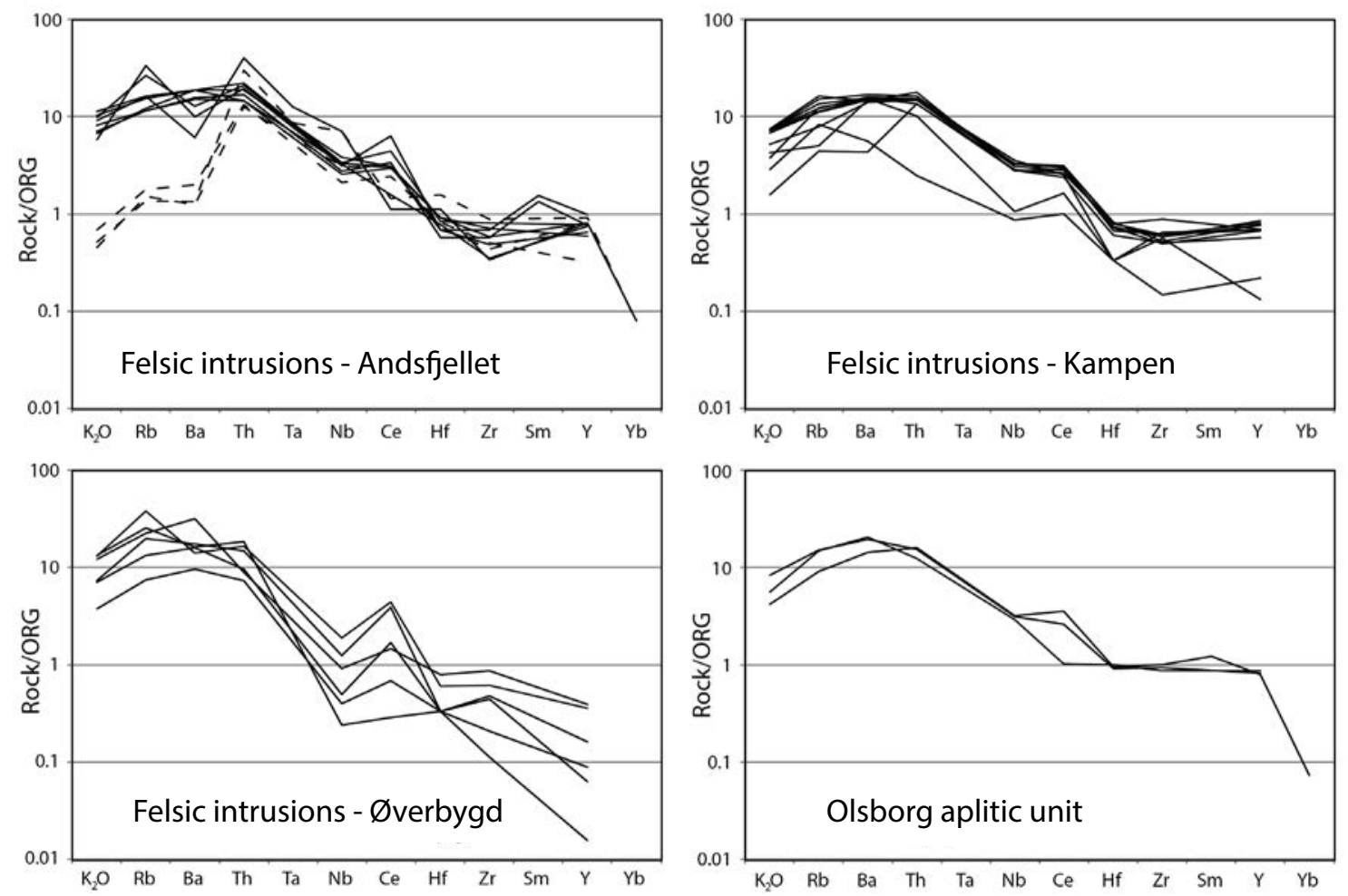

Figure 10. Felsic intrusive rocks from the main units normalised to Ocean Ridge Granite (ORG). Normalising data are taken from Pearce et al. (1984). 
reveal internal structures such as growth zoning and core-rim relationships (Fig. 12).

The zircons were analysed at the Geological Survey of Norway (NGU) on an ELEMENT XR single collector, high-resolution ICP-MS, coupled to a UP193-FX $193 \mathrm{~nm}$ short-pulse excimer laser ablation system from New Wave Research. Using a spot size of 20 or $15 \mathrm{~mm}$, a repetition rate of $10 \mathrm{~Hz}$ and an energy corresponding to a fluence of $4-5 \mathrm{~J} / \mathrm{cm}^{2}$, the laser was set to ablate single, up to $60 \mathrm{~mm}$-long lines. Each analysis included $30 \mathrm{~s}$ of background measurement followed by $30 \mathrm{~s}$ of ablation. The ICP-MS set-up measures masses 202, 204, 206-208, 232 and 238. The reference material GJ-1 (Jackson et al., 2004) was used for correction of isotopic ratios, whereas 91500 (Wiedenbeck et al., 1995) and an in-house standard (OS-99-14; $1797 \pm 3$ Ma; Skår, 2002) were used for checking precision and accuracy. The data were not corrected for common lead, but monitoring of the signal from 204 allowed exclusion of affected data from further calculations. The data were reduced using the GLITTER ${ }^{\circledR}$ software (van Achterbergh et al., 2001). The Isoplot program (Ludwig, 2003) was used to regress and present the $\mathrm{U}-\mathrm{Pb}$ isotope data (Fig. 13).

\section{Sample 065045, granite/granodiorite, Kampen intrusion}

This is a homogeneous, relatively fine-grained (0.2-0.5 $\mathrm{mm}$ grains), foliated granite/granodiorite with quartz, $\mathrm{K}$-feldspar and plagioclase as the main phases. Biotite is subordinate, partly present in scattered domains with some clinoamphibole. Late muscovite is associated with the biotite domains.

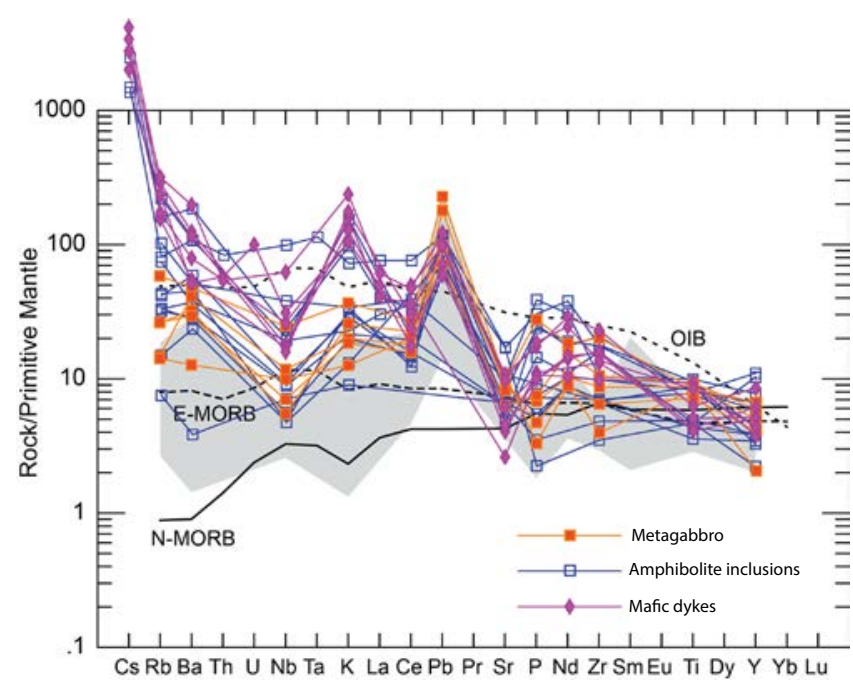

Figure 11. Mafic rocks from Andsfjellet plotted in primitive mantlenormalised diagram. The range of the Myrefjellet greenstone samples is shown in grey shading for comparison. Normalising values are taken from Sun \& McDonough (1989).
The zircons are short prismatic, oscillatory zoned and range in size between 75 and $100 \mu \mathrm{m}$ (Fig. 12A). Nine, mainly weakly discordant analyses define a discordia with upper and lower intercept ages of $2108 \pm 24$ and $318 \pm 670 \mathrm{Ma}$, respectively (MSWD $=0.14$; Fig. $13 \mathrm{~A})$. The upper intercept age is interpreted to reflect crystallisation of the granite. The significance of the lower intercept age, if any, is unclear.

\section{Sample 065066, granite/granodiorite, Kampen intrusion}

This is a homogeneous, medium-grained (1-2 mm) granodiorite, with plagioclase and quartz as the main mineral phases and K-feldspar as a subordinate phase. Muscovite and carbonate are accessory phases. Some of the feldspar grains are crushed and quartz shows undulose extinction.

The zircons are prismatic with well-developed oscillatory and sector zoning and range in size between 75 and $100 \mu \mathrm{m}$ (Fig. 12B). Ten analyses yield rather scattered, concordant to discordant data. Excluding one older outlier, the remaining nine analyses define a discordia with upper and lower intercept ages of $1941 \pm 59$ and $338 \pm$ $290 \mathrm{Ma}$, respectively (MSWD = 4.0; Fig. 13B). The upper intercept age is interpreted to reflect crystallisation of the granite, whereas the significance of the lower intercept age, if any, is unclear. Despite the rather poorly defined age from this sample, it is clearly younger than sample 065045, also from the Kampen intrusion.

\section{Sample 065038, trachyte, Øverbygd intrusions}

The rock is porphyric with coarse plagioclase (up to $\mathrm{cm}$ grains) in a more fine-grained, dark matrix of biotite, clinoamphibole, K-feldspar and some quartz. Epidote and titanite are accessory phases.

The zircons are stubby to short prismatic with welldeveloped oscillatory zoning, and range in size between 50 and $100 \mu \mathrm{m}$ (Fig. 12C). Twelve analyses yield mainly concordant to weakly reverse discordant data (Electronic Supplement 2). Excluding one 5\% reversely discordant analysis, the remaining eleven analyses yield a concordia age of $1892 \pm 10 \mathrm{Ma}$ (MSWD of concordance $=6.3$; Fig. 13C), interpreted as the best estimate of the crystallisation age of the trachyte.

\section{Sample 065072, trondhiemite, Øverbygd intrusions}

The rock is leucocratic and very low in $\mathrm{Fe}-\mathrm{Mg}$ phases; only a few scattered grains of biotite are present. It is medium grained (0.5-2 mm grains) with quartz and plagioclase as the main phases, while K-feldspar and muscovite are subordinate mineral phases. 

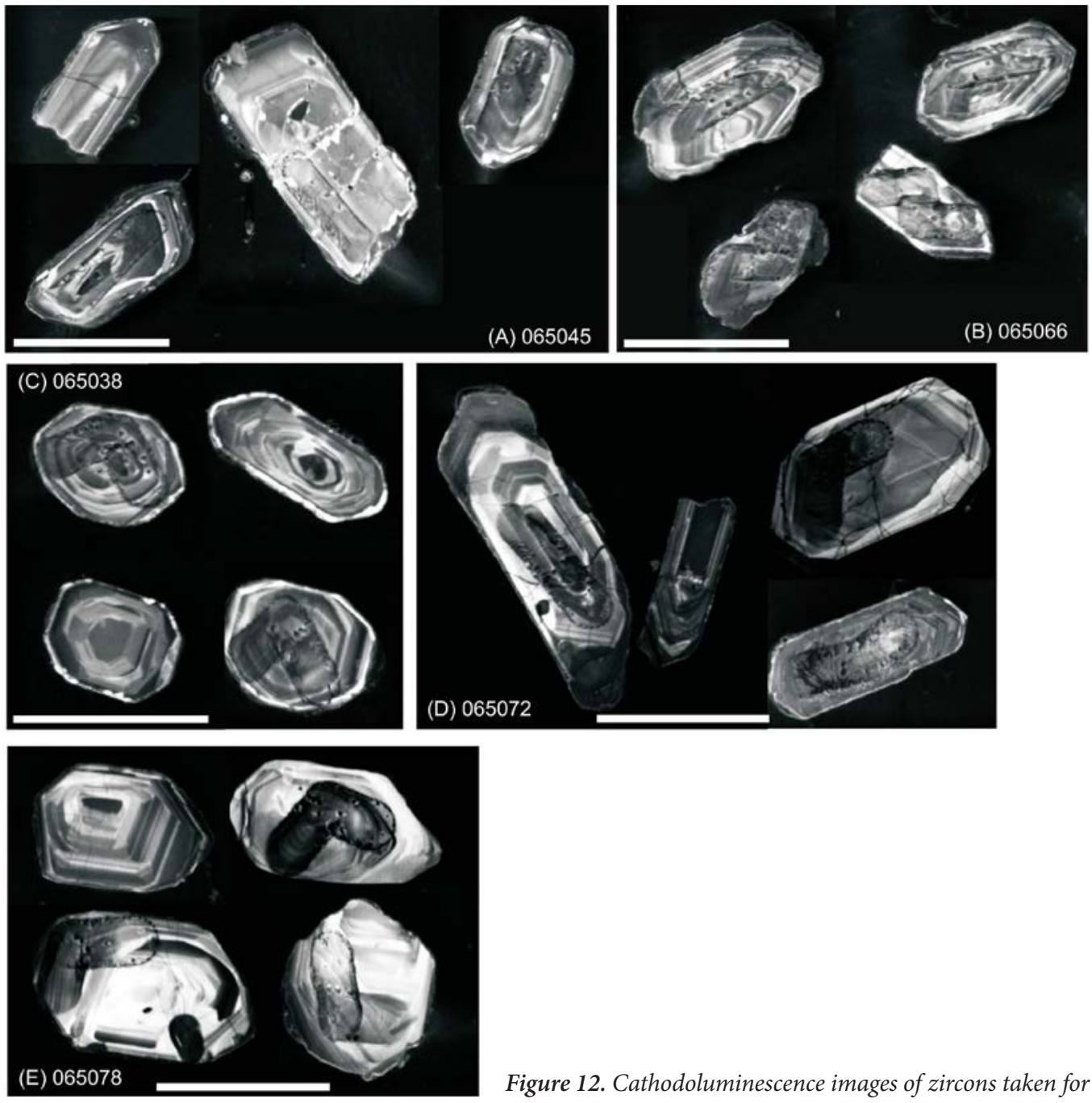

Figure 12. Cathodoluminescence images of zircons taken for dating. Scale bars are $100 \mu \mathrm{m}$.

The zircons are prismatic with well-developed oscillatory zoning, and range in size between 75 and $200 \mu \mathrm{m}$ (Fig. 12D). Twelve variably discordant analyses define a discordia with upper and lower intercept ages of $2836 \pm 15$ and $360 \pm 52 \mathrm{Ma}$, respectively (MSWD = 1.4; Fig. 13D). The former is interpreted as the crystallisation age of the trondhjemite from the Øvrebygd intrusions, whereas the latter may reflect Caledonian $\mathrm{Pb}$ loss. Unlike the other samples presented here, the zircons from this sample were quite high in common $\mathrm{Pb}$, and a common-Pb correction was applied to the data following the method of Andersen (2002). The zircons are also significantly higher in $U$ than for the other samples, which probably left the zircons more susceptible to $\mathrm{Pb}$ loss during low-grade Caledonian metamorphism.

\section{Sample 065078, granite, Øverbygd intrusions}

The rock is foliated, has varying grain size and contains lenses of quartz. It is leucocratic with only accessory biotite, chlorite and titanite. Quartz, K-feldspar and plagioclase are the dominating mineral phases, occurring in 0.1 to $2-3 \mathrm{~mm}$ grains.

The zircons are stubby to prismatic, have well-developed oscillatory zoning and range in size from 50 to $150 \mu \mathrm{m}$ (Fig. 12E). Some grains show core-mantle relationships, with thick, oscillatory-zoned rims surrounding and transecting oscillatory-zoned cores (Fig. 13E). The cores and rims yield similar ages and most likely reflect growthresorption processes in the magma. Twelve analyses yield concordant to weakly discordant data that define upper and lower intercept ages of $2405 \pm 24$ and $595 \pm 600 \mathrm{Ma}$, respectively (MSWD =0.68; Fig. 13E). The upper intercept age is interpreted to reflect crystallisation of the granite, whereas the significance of the lower intercept age, if any, is unclear.

In summary, the two samples from the Kampen granodiorite give ages of $1941 \pm 59 \mathrm{Ma}$ and $2108 \pm 24 \mathrm{Ma}$, while the three samples from the Øverbygd intrusions show a very large age span: $1892 \pm 10 \mathrm{Ma}$ (trachyte), $2405 \pm 24$ $\mathrm{Ma}$ (granite) and $2836 \pm 15 \mathrm{Ma}$ (trondhjemite). 

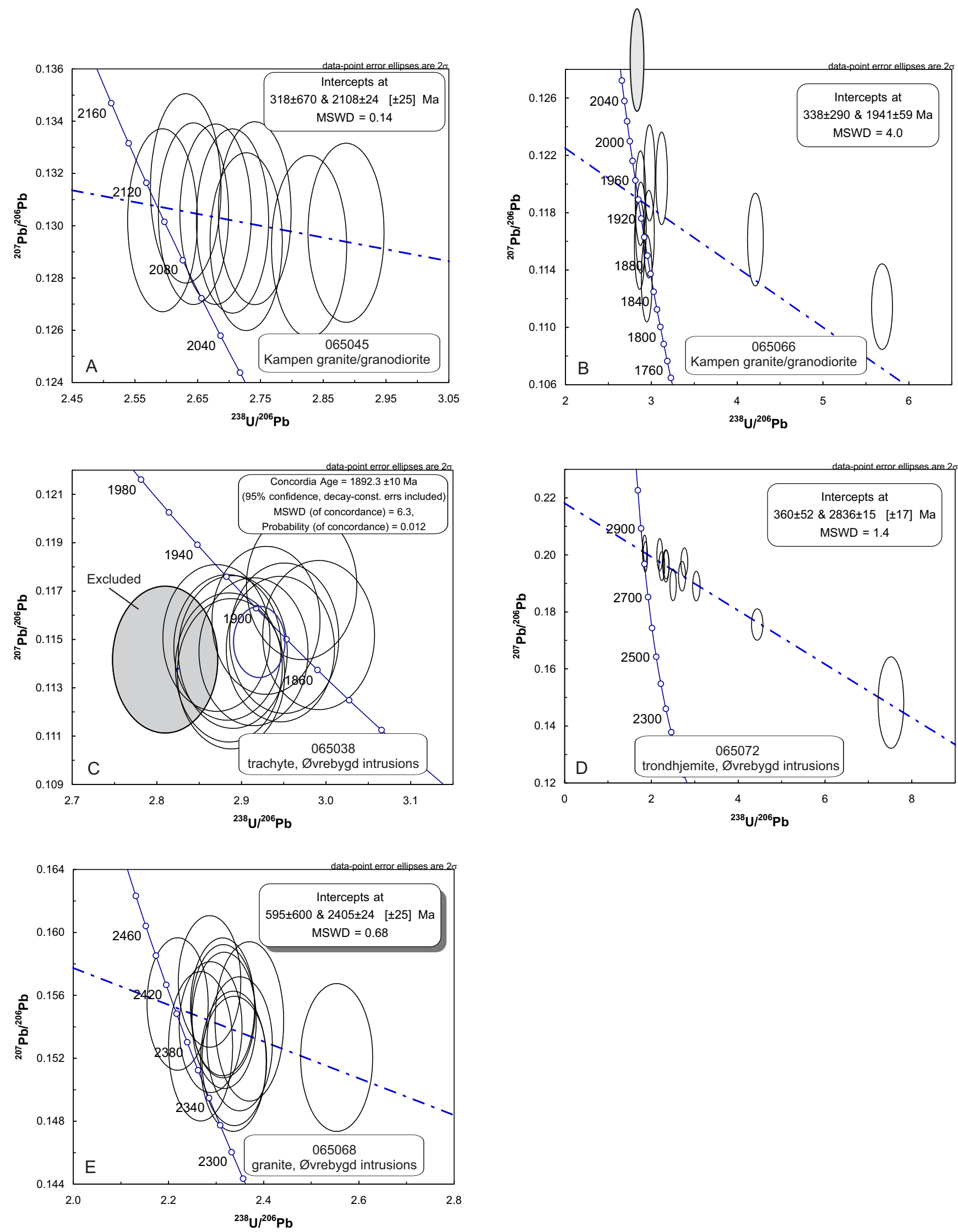

Figure 13. Geochronology (Tera-Wasserburg plots) of felsic intrusive rocks in the Mauken window. Sample 65045 - the central Kampen granitic to granodioritic intrusion, 65066 - the eastern part of central Kampen granitic to granodioritic intrusion, 65038 - a trachytic rock in the Øverbygd area, 65068 - a granite in the Øverbygd area, 65072 - a trondhjemitic rock in the Øverbygd area (see Fig. 2 for locations). 
Table 1. Geochemical data from the 'Main Zone' at Mauken. For location of samples, see Fig. 16 (S in wt.\%, otherwise ppm).

\begin{tabular}{|c|c|c|c|c|c|c|c|c|c|c|}
\hline & $T B-M A 46$ & TB-MA 47 & $T B-M A \_1$ & $T B-M A 48$ & TB-MA 49 & TB-MA 50 & $T B-M A 52$ & $J S S \_2$ & $T B-M A 71$ & $J S S \_1$ \\
\hline$S$ & 0.16 & 0.13 & 0.39 & 0.05 & 0.10 & 1.09 & 0.74 & 1.26 & 0.89 & 0.94 \\
\hline $\mathrm{Au}$ & 0.006 & 0.004 & 0.343 & 0.002 & 0.008 & 3.98 & 1.065 & 0.013 & 0.055 & 0.884 \\
\hline As & 17.1 & 9.3 & 1820 & 52.1 & 26.5 & 9760 & 5620 & 54.4 & 110.5 & 9500 \\
\hline $\mathrm{Cu}$ & 146 & 141 & 57 & 32 & 25 & 80 & 63 & 147 & 159 & 75 \\
\hline $\mathrm{Zn}$ & 84 & 115 & 119 & 86 & 104 & 74 & 67 & 564 & 107 & 81 \\
\hline $\mathbf{P b}$ & 15 & 15 & 17 & 16 & 29 & 38 & 24 & 27 & 35 & 19 \\
\hline Ag & 0.24 & 0.17 & 0.15 & 0.05 & 0.06 & 0.45 & 0.15 & 0.4 & 0.44 & 0.26 \\
\hline $\mathrm{Sb}$ & 0.47 & 0.41 & 9.05 & 1.85 & 4.34 & 25.3 & 26.7 & 9.61 & 14.4 & 38.3 \\
\hline $\mathrm{Bi}$ & 0.19 & 0.12 & 0.58 & 0.11 & 0.04 & 0.68 & 0.45 & 2.12 & 0.86 & 1.27 \\
\hline $\mathrm{Te}$ & 0.08 & 0.06 & 0.14 & $<0.05$ & $<0.05$ & 0.51 & 0.22 & 0.59 & 0.6 & 0.52 \\
\hline Co & 34.6 & 32.9 & 11 & 17.7 & 7.3 & 19.7 & 44.8 & 24.5 & 21 & 20.2 \\
\hline $\mathrm{Ni}$ & 157 & 167.5 & 31.3 & 48.9 & 38.9 & 45.6 & 34.4 & 91.7 & 60.5 & 36.9 \\
\hline Mo & 0.74 & 0.52 & 1.91 & 0.35 & 0.23 & 0.21 & 0.2 & 4.42 & 10.1 & 1.78 \\
\hline $\mathbf{B a}$ & 390 & 460 & 530 & 720 & 1020 & 600 & 1630 & 550 & 990 & 450 \\
\hline $\mathrm{Ga}$ & 21.2 & 21.2 & 26.2 & 19.35 & 19.5 & 19 & 22 & 23.4 & 23.4 & 19.45 \\
\hline $\mathrm{Ge}$ & 0.12 & 0.16 & 0.13 & 0.16 & 0.16 & 0.18 & 0.24 & 0.15 & 0.16 & 0.13 \\
\hline In & 0.03 & 0.07 & 0.05 & 0.06 & 0.05 & 0.06 & 0.06 & 0.07 & 0.05 & 0.07 \\
\hline $\mathrm{Se}$ & 1 & 1 & 2 & 1 & 1 & 2 & 1 & 3 & 3 & 2 \\
\hline Sn & 1.7 & 1.5 & 1.9 & 2.2 & 0.8 & 1.2 & 1.6 & 2.1 & 2.6 & 2.5 \\
\hline Cd & 0.20 & 0.15 & 0.20 & 0.11 & 0.15 & 0.18 & 0.14 & 4.36 & 0.11 & 0.11 \\
\hline W & 0.5 & 0.7 & 4.9 & 4.1 & 1.7 & 6.9 & 7.6 & 1.7 & 3.5 & 4 \\
\hline $\mathrm{Cr}$ & 225 & 249 & 139 & 106 & 96 & 105 & 127 & 157 & 154 & 91 \\
\hline V & 193 & 195 & 140 & 89 & 103 & 106 & 113 & 164 & 168 & 89 \\
\hline $\mathbf{L a}$ & 18.4 & 25.5 & 22 & 39.4 & 32.7 & 38.5 & 49.5 & 21.3 & 31.2 & 34.4 \\
\hline $\mathrm{Ce}$ & 42.1 & 54.6 & 49.2 & 86.5 & 67.4 & 85.8 & 106.5 & 45.9 & 58.2 & 72.5 \\
\hline $\mathbf{Y}$ & 17 & 19 & 17 & 27 & 16 & 16 & 26 & 19 & 20 & 24 \\
\hline $\mathrm{Zr}$ & 77 & 76 & 116 & 115 & 28 & 40 & 42 & 98 & 111 & 121 \\
\hline $\mathrm{Be}$ & 1.3 & 1.4 & 2.8 & 1.7 & 1.3 & 1.5 & 2.5 & 1.9 & 2.1 & 1.9 \\
\hline Hf & 2.3 & 2.3 & 3.5 & 3.2 & 0.8 & 1.1 & 1.2 & 2.9 & 3.3 & 3.7 \\
\hline $\mathrm{Ta}$ & 0.6 & 0.6 & 1.2 & 1.0 & 0.4 & 0.3 & 0.6 & 0.8 & 0.8 & 0.9 \\
\hline $\mathrm{Nb}$ & 8.6 & 8.0 & 14.2 & 11.7 & 6.5 & 4.7 & 9.1 & 9.3 & 9.9 & 10.4 \\
\hline $\mathbf{R b}$ & 55 & 95 & 84 & 182 & 127 & 110 & 158 & 157 & 135 & 106 \\
\hline $\mathrm{Sr}$ & 182 & 201 & 366 & 88 & 218 & 308 & 213 & 101 & 128 & 233 \\
\hline $\mathbf{U}$ & 2.0 & 2.1 & 3.0 & 3.2 & 0.7 & 0.8 & 1.7 & 5.1 & 5.5 & 2.5 \\
\hline Th & 5.7 & 7.2 & 8.9 & 12.3 & 6.8 & 8.2 & 10 & 9.3 & 11.4 & 12.4 \\
\hline $\mathrm{Sc}$ & 27 & 30 & 18 & 14 & 13 & 14 & 16 & 25 & 24 & 14 \\
\hline Tl & 0.5 & 0.5 & 0.9 & 0.9 & 0.9 & 0.7 & 0.9 & 1.3 & 0.8 & 0.8 \\
\hline Cs & 3.5 & 4.3 & 9.0 & 10.8 & 11.5 & 6.7 & 7.7 & 12.3 & 7.3 & 6.3 \\
\hline $\mathbf{L i}$ & 61 & 79 & 57 & 48 & 46 & 34 & 50 & 61 & 43 & 48 \\
\hline
\end{tabular}

\section{Gold mineralisation}

The Scandinavian Highlands company started their prospecting campaign in the Mauken area in 2007 and soon discovered gold anomalies in their stream sediment samples. Further work, including geophysics, soil sampling, mapping and rock sampling led to the discovery of the so-called 'Main Zone' gold mineralisation, hosted in sedimentary rocks close to the contact to the massive greenstone (Fig. 14).

On the basis of trenching and chip sampling at several localities along the zone, gold values up to $6 \mathrm{~g} / \mathrm{t}$ were found in a zone 4-6 m wide and over a length of $1800 \mathrm{~m}$ (Scandinavian Highlands press release, 2011). The zone was drilled at two localities in 2010 (total of $680 \mathrm{~m}$ and 6 


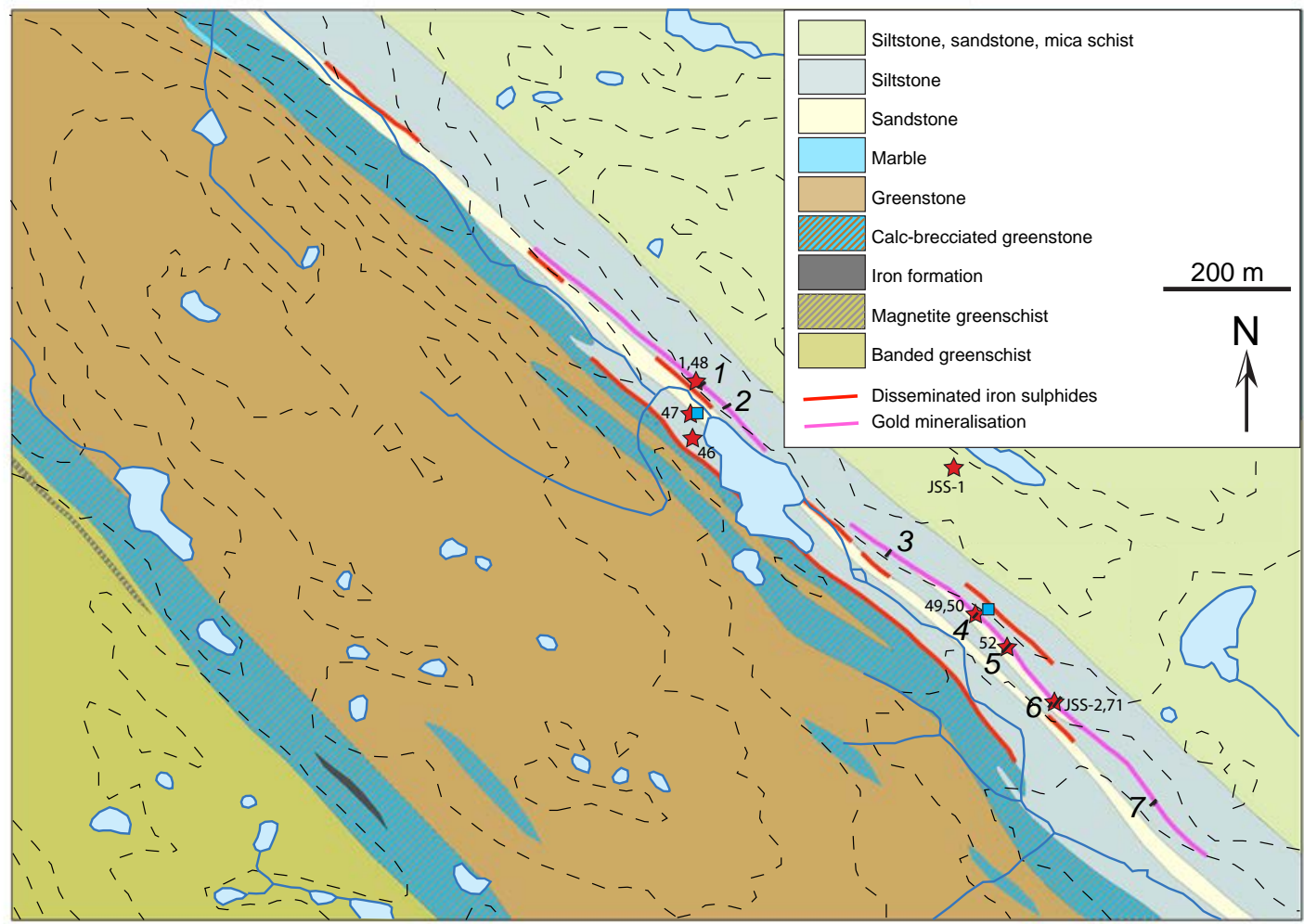

Figure 14. Geology of the 'Main Zone' gold mineralisation. The numbers 1-7 refer to trenches/sections with chip sampling carried out by the Scandinavian Highlands prospecting company. Blue squares are sites for diamond drilling. Numbered stars refer to samples in Table 1 .

holes; see Fig. 14), but the results of the drilling were not promising and their investigations came to an end in 2013.

Detailed mapping of the area around the 'Main Zone' has been carried out as part of this project (Fig. 14). A number of samples were also taken from the mineralisation, as well as the host rock (analytical data in Table 1).

The mineralisation is situated c. $100 \mathrm{~m}$ structurally and stratigraphically above the contact to the massive greenstone, in a steep to vertically dipping sequence of interbedded siltstone and sandstone (Fig. 14; see above). The contact to the structurally underlying greenstone is marked by a 50-100 m layer of calc-brecciated greenstone, which includes thin lenses of calcite marble.

The main mineralisation is hosted by fine-grained siltstone and sandstone. The maximum thickness is $2.5-2.7$ $\mathrm{m}$. The sequence is very little deformed and sedimentary structures such as cross-bedding and graded bedding (Fig. 6) are common, and these structures indicate that
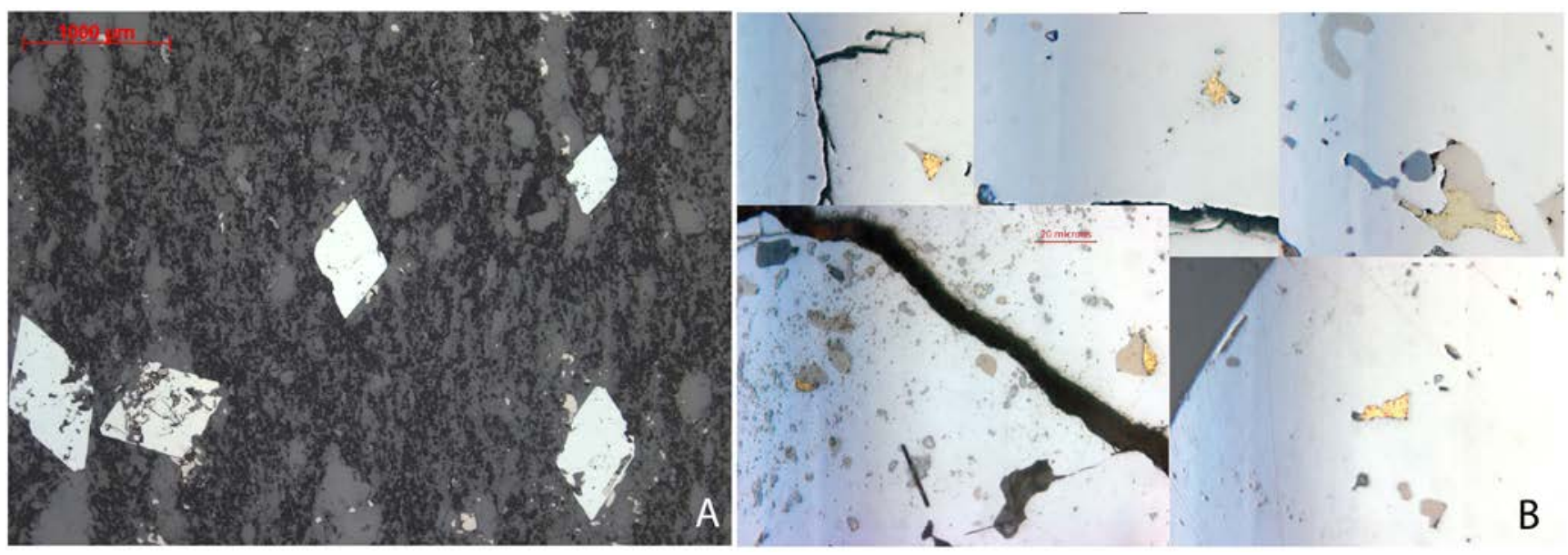

Figure 15. (A) Photomicrograph (reflected light) of idioblastic arsenopyrite grains. Irregular smaller grains are mainly pyrrhotite (sample TBMA 52). (B) Collage of photomicrographs showing 10-20 $\mu \mathrm{m}$ gold grains as inclusions in arsenopyrite. 


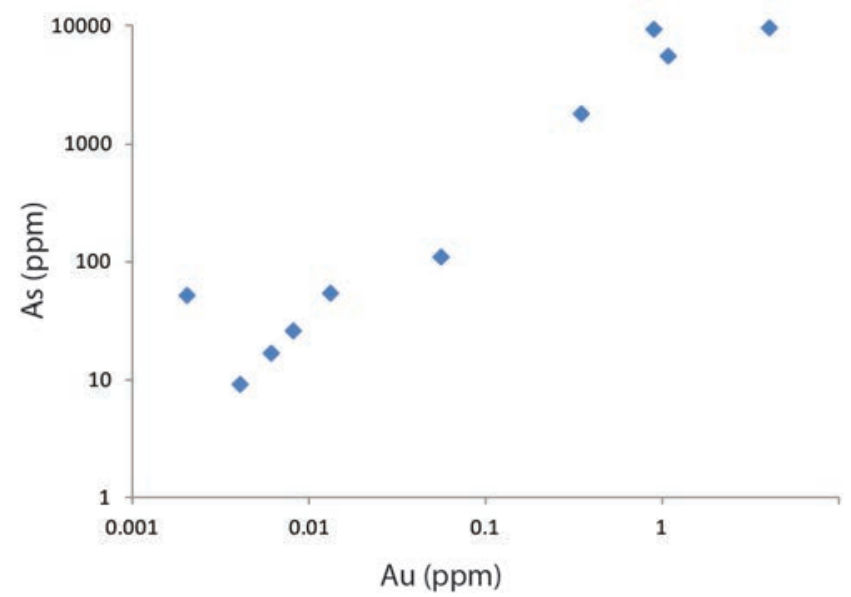

Figure 16. Plot of Au vs. As in samples from the 'Main Zone' and associated metasediments.

the mineralised sequence has right-way-up towards the northeast.

The metasedimentary rocks consist of irregular clastic grains of feldspar and quartz in a very fine-grained matrix of biotite and muscovite. Tourmaline is a common accessory mineral, the boron indicating a sea-water environment. The matrix minerals are commonly overgrown by late-stage clinozoisite/epidote and muscovite.

Arsenopyrite and pyrrhotite are the main sulphide minerals and occur mainly disseminated, but are locally concentrated in thin bands. Chalcopyrite is a common accessory phase, associated with pyrrhotite. The arsenopyrite grains are quite commonly associated with elongate quartz aggregates or lenses, while the hosting sedimentary rocks commonly show a varying degree of sericitisation in bands close to the sulphides.

Arsenopyrite occurs as hypidioblastic to idioblastic elongated grains, up to several $\mathrm{mm}$ in length (Fig. 15A). It contains inclusions of the other sulphides, and appears to be a later phase than these.

As shown in Fig. 15B, gold occurs as small (10-20 mm) inclusions in arsenopyrite. A few small inclusions of gold are found in pyrrhotite and are also present in the silicate matrix.

Data of samples from the mineralisation (Table 1) show that the mineralisation contains only gold and arsenic (up to $4 \mathrm{ppm} \mathrm{Au}$ and $0.98 \% \mathrm{As}$ ), while contents of base metals such as $\mathrm{Cu}, \mathrm{Zn}$ and $\mathrm{Pb}$ are less than a few hundreds of ppm. Gold is strongly correlated with arsenic (Fig. 16), and confirms the close relationship between the two elements.

Gold has also been found c. $200 \mathrm{~m}$ farther to the north in the sedimentary rocks. This mineralisation (marked by sample JSS-1 in Fig. 14) consists of weak dissemination of arsenopyrite and pyrite in thin quartz veins in fine-grained sandstone. Very fine-grained gold $(10 \mathrm{~mm})$ is present as inclusions in arsenopyrite. In addition to quartz, the veins contain chlorite and lesser amounts of biotite and muscovite. One analysis yields $0.9 \mathrm{ppm} \mathrm{Au}$ and $0.95 \%$ As (Table 1).
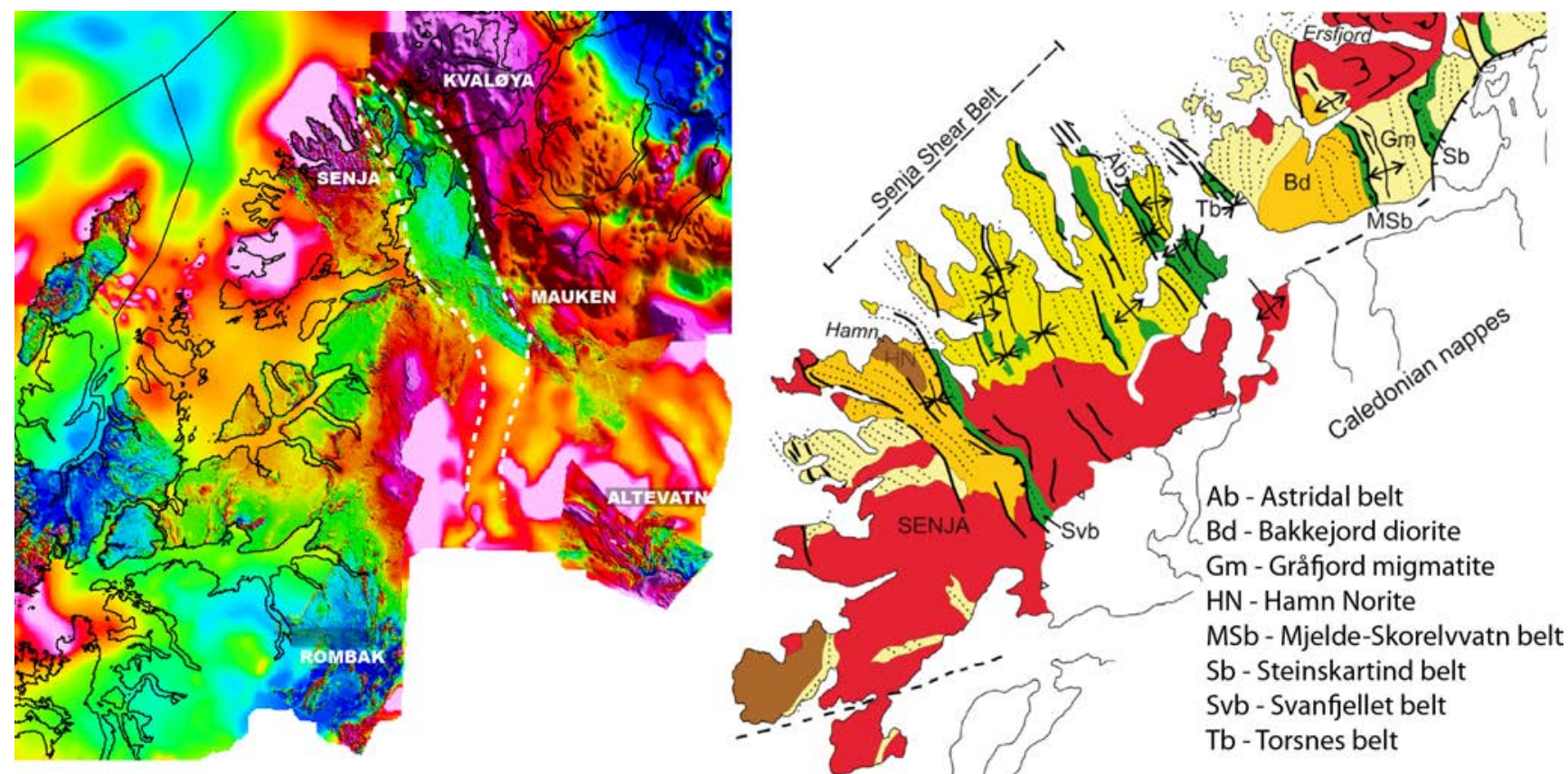

Figure 17. (Left) Regional magnetic data in southern Troms (both high-resolution new data and older low-resolution data). From Nasuti et al. (2015). The stippled white lines show the most likely continuation of the Mauken basement window. (Right) Overview of the geology in the Malangen area (from Bergh et al., 2010). 


\section{Summary and discussion}

The Mauken window consists of supracrustal and intrusive rocks of Archaean to Palaeoproterozoic ages, and of different tectonic origin.

Geochemistry of the greenstone unit in the Myrefjell Formation indicates an arc/back-arc affinity (Fig. 9). The Aurevatn Formation lying on top of the Myrefjell Formation consists of clastic sedimentary rocks like siltstone and sandstone, partly forming turbiditic units. On this basis, the Målselva Group must have been formed close to a continent.

With respect to age relationships, the felsic AndsfjellKampen intrusions are younger than the Myrefjell Formation in the Målselva Group. This is based on cross-cutting relationships (Fig. 3). The Kampen granodiorite that transects the greenstone was dated to $2108 \mathrm{Ma}$ (Figs. 12 \& 13), meaning that the Myrefjell Formation is at least Palaeoproterozoic in age.

The contact between the Øverbygd intrusions and the Målselva Group is a major shear structure, which implies that the age relationship between these two units is not known. The ages obtained from the Øverbygd intrusions range from $1892 \mathrm{Ma}$ to $2836 \mathrm{Ma}$. Thus, the intrusive rocks from this area show ages both younger and older than the Andsfjell-Kampen intrusions.

\section{Regional correlations}

Since the Mauken basement window is situated between the basement in the Altevatn area to the east and the West Troms Basement Complex (WTBC) to the west (Fig. 1), it is natural to look for continuations and correlations of the Mauken lithologies in these separate areas.

The WTBC comprises Neoarchaean to Palaeoproterozoic tonalitic to granitic gneisses and supracrustals, intruded by Late Palaeoproterozoic (1800-1760 Ma) plutonic suites (e.g., Bergh et al., 2010). The complex is bounded to the east by Mesozoic normal faults of the VestfjordenVanna Fault Complex (Olesen et al., 1997). Parts of this fault complex show a vertical displacement of more than 1000 m (op. cit.).

Since the package of Caledonian nappes is comparatively thin in the central Troms area, the regional magnetic data may provide clues as to the most likely continuations of the Mauken basement window lithologies. The regional magnetic data are shown in Fig. 17, and include both old low-resolution and new high-resolution data (collected by NGU). The Målselva Group mainly shows a very low magnetic response, and this low-magnetic anomaly seems to continue towards the northwest, under the Caledonian nappes, to the outer Malangen area between
Senja and Kvaløya. Similar conclusions were made by Olesen et al. (1997), who named this fault-bounded, lowmagnetic belt the Lenvik zone, and interpreted it to be part of the Bothnian-Senja fault complex.

In the outer Malangen area there are two belts of supracrustal rocks, namely the Torsnes and Astridal belts ( $\mathrm{Ab}$ and $\mathrm{Tb}$ in Fig. 17). The Astridal belt on Senja comprises greenschist- to amphibolite-facies metavolcanic and metasedimentary rocks, including relict pillow-lava, tuffite, marble, calcareous mica schist and a thick pile of well-preserved, partly cross-bedded psammite (Fareth, 1983; Bergh et al., 2010). This rock assemblage is quite similar to the Målselva Group. The depositional age of the supracrustals in the Astridal belt is not known. The nature of the contact to the surrounding granitic gneisses is also unclear; it has not been possible to determine whether or not the supracrustals were deposited on top of the gneisses, because of the strong deformation (Zwaan, 1995).

The Torsnes belt on the southern tip of Kvaløya comprises metaconglomerates, psammites, mica schist and amphibolite, all of which are partly mylonitised (Bergh et al., 2010). Furthermore, a maximum depositional age of $1970 \mathrm{Ma}$ was obtained from detrital zircons (Myhre et al., 2011). On this basis, the Torsnes belt is probably not a candidate for correlation with the Målselva Group, at least not for the Myrefjell volcanites (it should be noted that we have no age constraints for the Aurevatn formation).

The geology of Kvaløya includes the Mjelde-Skorelvvatn and Steinskartind units, both of which are believed to be around $2000 \mathrm{Ma}$ (a metavolcanic lens in the former was dated at $1998 \mathrm{Ma}$; Corfu et al., 2006), and younger than the Myrefjell Formation. Even farther north is the Ringvassøya greenstone belt, which is Neoarchaean (2850-2830 Ma; Motuza et al., 2001; Kullerud et al., 2006). It comprises mafic, intermediate and felsic metavolcanic rocks with tholeiitic to calc-alkaline affinities, which do not fit with the geochemistry of the Myrefjell volcanites. On the island of Vanna to the north of Ringvassøya, a metasedimentary assemblage named the Vanna Group was deposited between 2.40 and 2.22 $\mathrm{Ga}$ (Bergh et al., 2010).

The large age span of the intrusive units at Mauken (1892 to $2836 \mathrm{Ma}$ ) makes it difficult to correlate these units with other specific intrusions. Ages obtained on felsic complexes in the WTBC are mainly within the range 2560 to $2885 \mathrm{Ma}$ (e.g., Bergh et al., 2010; Myhre et al., 2013 and references therein). This fits with the older age of $2836 \mathrm{Ma}$ from the Øverbygd trondhjemite, but the younger ages of 1900-2400 Ma have not been recorded in any of the felsic units in the surrounding basement areas.

Eastwards and southwards from Mauken, the low-magnetic signature of the supracrustals is diffuse, but does seem to extend towards the south (Fig. 17) and not 


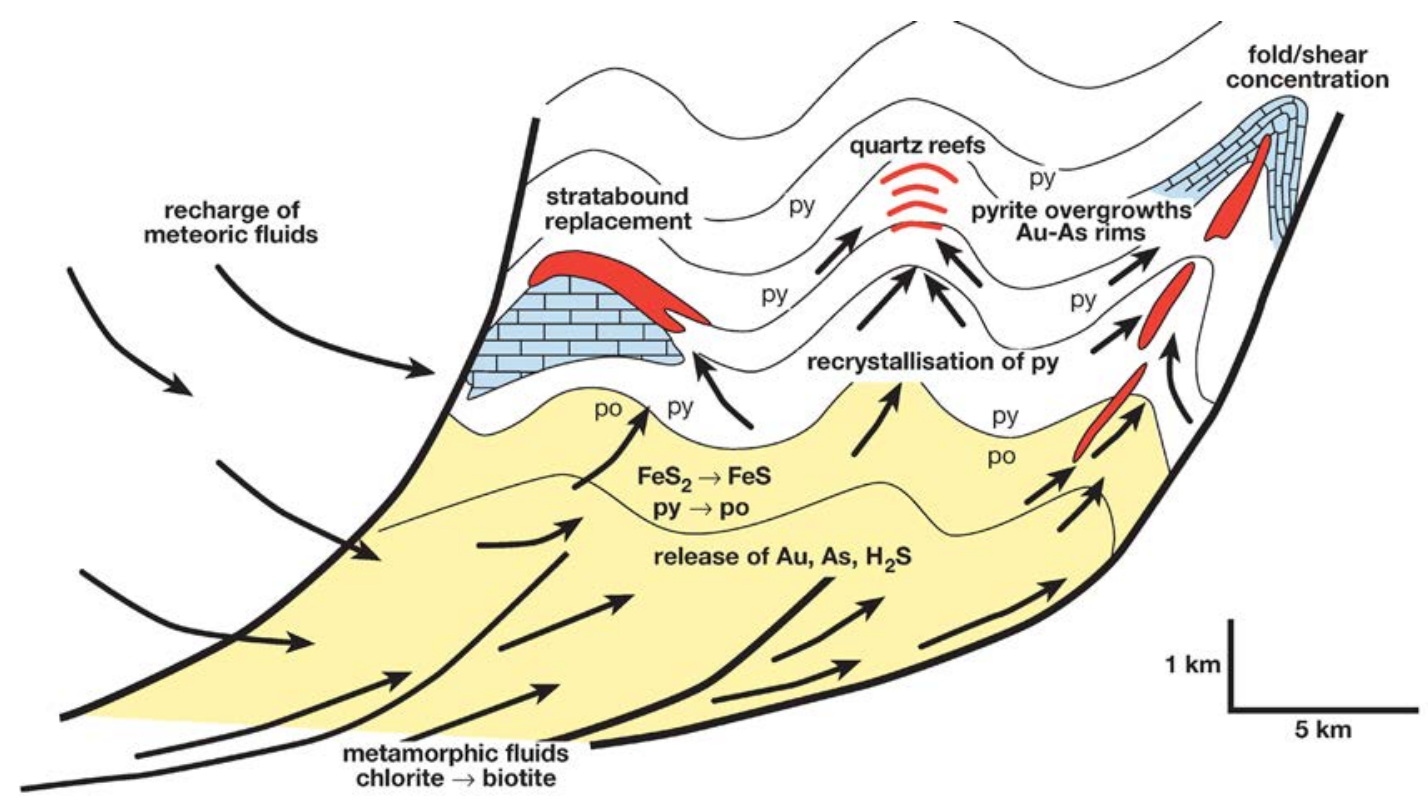

Figure 18. Model showing potential meteoric and metamorphic fluid pathways; gold, arsenic and sulphur are released from the carbonaceous sediments (yellow colour) by conversion of sedimentary pyrite to pyrrhotite deeper in the basin (mid to upper greenschist facies). Gold and arsenic are deposited in the upper stratigraphy (red colour), associated with focusing of fluids along faults and into anticlinal zones or shears, and along favourable rock contacts (e.g., limestone - blue colour; from Large et al., 2011).

eastwards into the Altevatn area. Furthermore, supracrustal units with low metamorphic grade are not known from the Altevatn basement area (Stølen, 1997; Slagstad et al., 2015). The diffuse magnetic signals are partly due to the lower quality of the data, but probably also due to thicker Caledonian nappes.

It is possible that the Målselva Group can be correlated with rocks in the eastern part of the Rombak Tectonic Window. In the Sjangeli area, 2150-2175 Ma transitional island-arc volcanic rocks (partly pillow lava), greywackes and fine-grained biotite schist are known (Korneliussen \& Sawyer, 1989; Romer, 1989). The 2150-2175 Ma age, however, is poorly constrained (based on $\mathrm{Sr}$ isotopes and mixing interpretations; Romer, 1989). Other data give ages younger than $1950 \mathrm{Ma}$ for supracrustal rocks in the southern part of the Rombak window. This is based on dating of a tonalitic gneiss which is interpreted to be the basement for the supracrustal package (see Angvik, 2014 and references therein). More data, such as geochronology and new high-resolution geophysics in the area between Mauken and Rombak, would perhaps solve the question of correlation.

\section{Gold mineralisations}

The only significant gold mineralisation found in the Mauken window is the so-called 'Main Zone'. The 'Main Zone' is localised in sandstone/siltstone close to the contact to underlying greenstone, and this contact zone may have been important with respect to the formation of the mineralisation.
The restricted thickness (up to $2.7 \mathrm{~m}$ ) and extent of the mineralised zone (some $600 \mathrm{~m}$ ), as well as its low grade (only sporadic $>1 \mathrm{ppm}$ gold), are clearly not economic. However, the zone disappears into a swampy area to the southeast and is covered by vegetation to the northwest.

One possible source of the gold and arsenic in this setting is that of carbonaceous sediments, which are known to concentrate a number of metals in early formed, diagenetic iron sulphides (Large et al., 2011; Thomas et al., 2011). At Mauken, close to the contact to the underlying greenstone, the siltstone is quite rich in graphite, and also contains minor amounts of iron sulphides.

Greenstone could also be a source for the gold, but the strong correlation and association of gold and arsenic (Fig. 16) strongly suggest that arsenic was transported and deposited together with gold. Since the content of arsenic is typically quite low in greenstone, this lithology is probably not the source of either arsenic or gold.

According to a model for orogenic gold deposits presented by Large et al. (2011), gold, arsenic and sulphur are preferentially released from the diagenetic sulphides because of recrystallisation during later metamorphism (Fig. 18). The resulting fluids may have followed structural pathways and deposited the metals higher up in the succession. In the case of Mauken, the fluids may have been concentrated along or close to the greenstone-sediment contact.

The gold mineralisation at Mauken is very different from the mineralisations on Ringvassøya in the WTBC. In 
the latter case, gold is related to sulphide-bearing quartz veins, where the quartz in the most gold-rich veins is sugary in character (e.g., Sandstad \& Nilsson, 1998). The veins are hosted by greenschist and greenstone (partly pillowed), cross-cut by granite and dolerite dykes, all assigned to the Ringvassøya greenstone belt (e.g., see Bergh et al., 2010).

In the Rombak tectonic window there are several $\mathrm{Au}$-As mineralisations, some of which are associated with fineto medium-grained metagreywacke and metasiltstone (Angvik, 2014). These particular mineralisations have been interpreted to be of orogenic type, related to shear zones and structures formed during the Palaeoproterozoic (op. cit.), but also show similarities with the Mauken mineralisation.

\section{Conclusions}

High-resolution geophysics followed up by geological fieldwork has led to the compilation of a new geological map for the Mauken basement window. Based on geochemistry, this work has shown that the supracrustal rocks of the Målselva Group were formed in an arc or back-arc environment, probably close to a continent. The Måsselva Group must have formed prior to $2108 \mathrm{Ma}$, which is the age of the cross-cutting granodiorite of the Andsfjell-Kampen intrusions.

Based on regional geophysics and similar geology, the Målselva Group may be correlated with the Astridal belt in the Senja shear belt to the west, and possibly with the eastern part of the Rombak window in the south.

The only significant gold mineralisation in the Mauken window is the so-called 'Main Zone'; however, this seems to be too small and low-grade to be of economic interest. The mineralisation, however, is interesting as it may represent a new type of gold occurrence (closely related to and situated in metasedimentary rocks) in Norway. A similar origin may be suggested for some of the $\mathrm{Au}-\mathrm{As}$ deposits in the Rombak tectonic window.

Acknowledgements. The work in the Mauken area was carried out under the NGU MINN programme and project no. 340400. Øivind Skår, Torkil Røhr and others at the NGU lab are thanked for assistance during sample preparation and analysis. Per Inge Myhre is thanked for valuable discussions in the field. Arild Andresen and Rune B. Larsen are thanked for valuable comments in their reviews of the manuscript. Per Terje Osmundsen is thanked for editorial handling of the manuscript.

\section{References}

Andersen, T. 2002: Correction of common lead in U-Pb analyses that do not report ${ }^{204} \mathrm{~Pb}$. Chemical Geology 192, 59-79.

Andresen, A., Fareth, E., Bergh, S., Kristensen, S.E. \& Krogh, E. 1985: Review of Caledonian lithotectonic units in Troms, north Norway. In Gee, D.G. \& Sturt, B.A. (eds.): The Caledonide orogen - Scandinavia and related areas, J. Wiley \& Sons, ltd., Chichester, pp. 569-578.

Angvik, T.L. 2014: Structural development and metallogenesis of Paleoproterozoic volcano-sedimentary rocks of the Rombak Tectonic Window. PhD thesis, Norwegian University of Science and Technology, NTNU, Trondheim, Norway, 283 pp.

Bergh, S.G., Kullerud, K., Armitage, P.E.B., Zwaan, K.B., Corfu, F., Ravna, E. \& Myhre, P.I. 2010: Neoarchean to Svecofennian tectonomagmatic evolution of the West Troms Basement Complex, North Norway. Norwegian Journal of Geology 90, 21-48.

Berthelsen, A. 1967: Geologic and structural studies around two geophysical anomalies in Troms, Northern Norway. Norges geologiske undersøkelse 247, 58-77.

Corfu, F., Kullerud, K. \& Bergh, S.G. 2006: U-Pb constraints on the late Palaeoproterozoic evolution of the West Troms Basement Complex, northern Norway (abstract). Geological Society of Finland Bulletin, Special Issue 1, p. 23.

Fareth, E. 1981: Bedrock map Tromsø, scale 1:250,000, preliminary version. Norges geologiske undersøkelse.

Fareth, E. 1982: Takvatnet. Bedrock map 1533 III, scale 1:50,000, preliminary version. Norges geologiske undersøkelse.

Fareth, E. 1983: Mefjordbotn, Bedrock map 1433 IV, scale 1:50,000, preliminary version. Norges geologiske undersøkelse.

Gustavson, M. 1963: Grunnfjellsvinduer i Dividalen, Troms. Norges geologiske undersøkelse 223, 92-105.

Gustavson, M. 1966: The Caledonian mountain chain of the southern Troms and Ofoten areas. Part I. Basement rocks and Caledonian meta-sediments. Norges geologiske undersøkelse 239, 1-162.

Jackson, S.E., Pearson, N.J., Griffin, W.L. \& Belousova, E.A. 2004: The application of laser ablation-inductively coupled plasma-mass spectrometry to in situ $\mathrm{U}-\mathrm{Pb}$ zircon geochronology. Chemical Geology 211, 47-69.

Kalsbeek, F. \& Olesen, N.Ø. 1967: A preliminary note on the geology of the area between Altevatn and Målselva, Indre Troms, N. Norway. Norges geologiske undersøkelse 247, 252-261.

Korneliussen, A. \& Sawyer, E.W. 1989: The geochemistry of Lower Proterozoic mafic to felsic igneous rocks, Rombak Window, North Norway. Norges geologiske undersøkelse Bulletin 415, 7-21.

Kullerud, K., Skjerlie, K.P., Corfu, F. \& de la Rosa, J. 2006: The 2.40 Ga Ringvassøy mafic dykes, West Troms Basement Complex, Norway: The concluding act of Early Palaeoproterozoic continental breakup. Precambrian Research 150, 183-200.

Landmark, K. 1959: Målselv. Bedrock map, scale 1:100,000, Tromsø Museum.

Landmark, K. 1967: Description of the geological maps 'Tromsø' and 'Målselv', Troms. I. The Precambrian window of Mauken Andsfjell. Norges geologiske undersøkelse 247, 172-207.

Large, R.R., Bull, S.W. \& Maslennikov, V. 2011: A carbonaceous sedimentary source-rock model for Carlin-type and orogenic gold deposits. Economic Geology 106, 331-358.

Le Bas, M.J., Le Maitre, R.W., Streckeisen, A. \& Zanettin, B. 1986: A Chemical Classification of Volcanic Rocks Based on the Total Alkali-Silica Diagram. Journal of Petrology 27, 745-750.

Lindahl, I. \& Nilsson, L.P. 2002: En vurdering av klebersteinspotensialet i Troms. Norges geologiske undersøkelse Report 2002.077, 93 pp. (in Norwegian).

Ludwig, K.R. 2003: Isoplot 3.00, A Geochronological Toolkit for Microsoft Excel. Berkley Geochronology Center Special Publication $4,1-74$.

Motuza, G., Motuza, V., Beliatsky, B. \& Savva, E. 2001: The Ringvassøya greenstone belt (Tromsø, north Norway): implications for 
a Mesoarchaean subduction zone. EUROPROBE time-slice symposium 'Archaean and Proterozoic Plate Tectonics: Geological and Geophysical Records', 1 October-3 November, St. Petersburg, Russia, pp. 43-44.

Myhre, P.I., Corfu, F. \& Bergh, S. 2011: Palaeoproterozoic (2.0-1.95Ga) pre-orogenic supracrustal sequences in the West Troms Basement Complex, North Norway. Precambrian Research 186, 89-100.

Myhre, P.I., Corfu, F., Bergh, S.G. \& Kullerud, K. 2013: U-Pb geochronology along an Archaean geotransect in the West Troms Basement Complex, North Norway. Norwegian Journal of Geology 93, 1-24.

Nasuti, A., Roberts, D., D umais, M.-A., Ofstad, F., Hyvönen, E., Stampolidis, A. \& Rodionov, A. 2015a: New high-resolution aeromagnetic and radiometric surveys in Finnmark and North Troms: linking anomaly patterns to bedrock geology and structure. Norwegian Journal of Geology 95, 217-243. http://dx.doi. org/10.17850/njg95-3-10.

Nilsson, L.P. \& Lindahl, I. 2005: Oppfølgende undersøkelse av utvalgte klebersteinsforekomster i Troms fylke. Norges geologiske undersøkelse Report 2005.084, 19 pp. (in Norwegian).

Olesen, O., Torsvik, T., Tveten, E., Zwaan, K.B., Løseth, H. \& Henningsen, T. 1997: Basement structure of the continental margin in the Lofoten-Lopphavet area, northern Norway: constraints from potential field data, on-land structural mapping and paleomagnetic data. Norwegian Journal of Geology 77, 15-30.

Pearce, J.A., Harris, N.B.W. \& Tindle, A.G. 1984: Trace element discrimination diagrams for the tectonic interpretation of granitic rocks. Journal of Petrology 25, 956-983.

Rodionov, A., Koziel, J. \& Lynum, R. 2012: Helicopter-borne magnetic, electromagnetic and radiometric geophysical survey in Mauken area, Målselv, Troms. Norges geologiske undersøkelse Report 2012.010, 25 pp.

Romer, R.L. 1989: Implications of isotope data on the metamorphism of the basic volcanites from the Sjangeli Window, northern Sweden. Norges geologiske undersøkelse Bulletin 415, 39-56.

Sandstad, J.S. \& Nilsson, L.P. 1998: Gullundersøkelser på Ringvassøy, sammenstilling av tidligere prospektering og feltbefaring i 1997. Norges geologiske undersøkelse Report 98.072, 68 pp. (in Norwegian).

Skår, Ø. 2002: U-Pb geochronology and geochemistry of early Proterozoic rocks of the tectonic basement windows in central Nordland, Caledonides of north-central Norway. Precambrian Research 116, 265-283.

Slagstad, T., Willemoes-Wissing, B., Coint, N., Stampolidis, A., Ganerød, M. \& Ofstad, F. 2015: Geology and metallogenic potential of the northwesternmost Norrbotten Province around Altevatn in Troms, northern Norway. Norwegian Journal of Geology 95, 445466. http://dx.doi.org/10.17850/njg95-3-07.

Stølen, L.-K. 1997: Bedrock geology of the Altevatn-Måskanvarri area, Indre Troms, northern Scandinavian Caledonides. Norges geologiske undersøkelse Bulletin 432, 5-23.

Sun, S.-s. \& McDonough, W.F. 1989: Chemical and isotopic systematic of oceanic basalts: implications for mantle composition and processes. Geological Society of London Special Publications 42, 313-345.

Thomas, H.V., Large, R.R., Bull, S.W., Maslennikov, V., Berry, R.F., Fraser, R., Froud, S. \& Moye, R. 2011: Pyrite and pyrrhotite and composition in sediments, laminated quartz veins, and reefs at Bendigo gold mine, Australia: Insights for ore genesis. Economic Geology 106, 1-32.

Van Achterbergh, E., Ryan, C., Jackson, S. \& Griffin, W.L. 2001: Appendix 3 data reduction software for LA-ICP-MS. In Sylvester, P. (ed.): Laser-ablation-ICP-MS in the Earth Sciences; Principles and Application, Mineralogical Association of Canada Short Course 29, pp. 239-243.

Wiedenbeck, M., Allé, P., Corfu, F., Griffin, W.L., Meier, M., Oberli, F., Von Quadt, A., Roddick, J.C. \& Spiegel, W. 1995: Three natural zircon standards for $\mathrm{U}-\mathrm{Th}-\mathrm{Pb}$, Lu-Hf, trace element and REE analyses. Geostandards Newsletter 19, 1-23.
Zwaan, K.B. 1995: Geology of the Precambrian West Troms Basement Complex, northern Norway, with special emphasis on the Senja Shear Belt: a preliminary account. Norges geologiske undersøkelse Bulletin 427, 33-36.

Zwaan, K.B., Fareth, E. \& Grogan, P.W. 1998: Bedrock map Tromsø, scale 1:250,000, Norges geologiske undersøkelse. 
